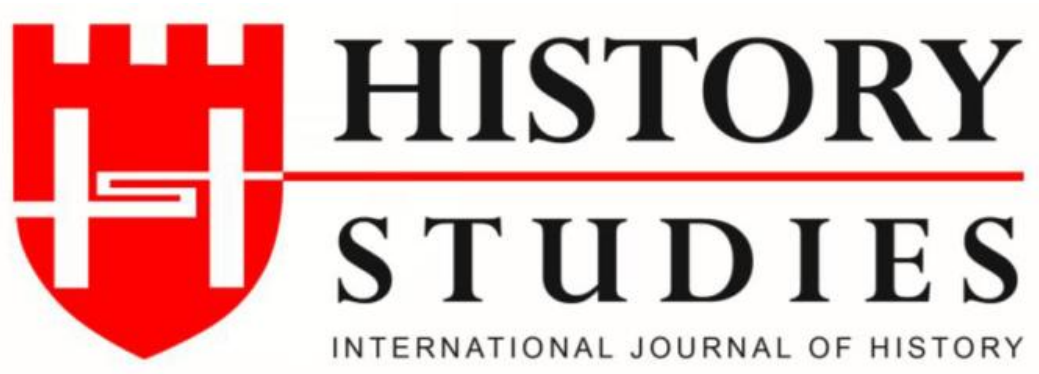

ISSN: 13094173 (Online) 1309 - 4688 (Print)

Volume 12 Issue 4, August 2020

DOI Number: 10.9737/hist.2020.888

Araştırma Makalesi

Makalenin Geliş Tarihi: 23.04.2020 Kabul Tarihi: 01.06.2020

Atıf Künyesi: Fehminaz Çabuk, “Osmanlı Devleti'nde Memurların Müdahil Olduğu Bazı Fuhuş ve

Fahişe Meseleleri Üzerine Bir Değerlendirme (1833-1922)", History Studies, 12/4, Ağustos 2020,

s. 1505-1523.

\title{
Osmanlı Devleti'nde Memurların Müdahil Olduğu Bazı Fuhuş ve Fahişe Meseleleri Üzerine Bir Değerlendirme (1833-1922)
}

\section{An Evaluation on Some Prostitution and Prostitute Issues Involved by Civil Servants in} the Ottoman State (1833-1922)

\author{
Dr. Fehminaz Çabuk \\ ORCID No: 0000-0002-1654-1763 \\ Ağrı İbrahim Çeçen Üniversitesi
}

Öz: Toplumun ahlakı, asayişi ve düzeni açısından tehdit oluşturan her mesele, Osmanlı Hükümeti tarafindan ciddiyetle takip edilmekte ve büyük sorunlara sebebiyet vermeden önü alınmaya çalışılmaktaydı. Fuhuş ve fahişeler de bu meselelerden sadece biriydi. Toplumun dini ve ahlaki yapısı, fuhuş ve fahişelere yaklaşımda önemli rol oynamaktaydı. Bir diğer ifadeyle dini ve ahlaki ögrretilere ters düşen, fuhuş ve fahişe meseleleri, toplumun oldukça hassas olduğu konulardı. Bu meseleler, Osmanlı'da büyük hadiselere dahi yol açmıştır. Bu bağlamda devlet görevlilerinin öncelikli vazifeleri, ülkenin inanç ve değerlerine gereken hassasiyeti göstererek, asayiş ve nizamı sağlamaktı. Ancak 19. yüzyılda batılı devletlerle ilişkiler, savaşlar, ekonomik buhranlar, Osmanlı toplum ve idarecilerinde ahlaki bozulmalara neden olmuş, devlet görevlileri daha fazla para kazanmak adına vazife ve yetkilerini kötüye kullanarak fuhuş ve daha birçok ahlaki sorunun artmasına, toplumda huzursuzluğa, asayişsizliğe ve şikâyetlere yol açmışlardır. Bu çalışmada, Osmanlı Devleti'nde mülkiye ve askeriyeden memurların, fahişelerle münasebetler kurarak umumi ahlaka aykırı davranışlar sergileyip görev ve yetkilerini ne şekilde kötüye kullandıkları, Osmanlı Hükümeti'nin ilgili dairelerine intikal etmiş bazı şikâyetler üzerinden irdelenerek Osmanlı'da memurlarında müdahil olduğu fuhuş ve fahişe meselelerine dair kısa bir değerlendirme yapılmaya çalışılmaktadır.

Anahtar Kelimeler: Devlet Görevlileri, Fuhuş, Fahişe, Ahlak, Osmanlı Devleti

Abstract: Every issue that posed a threat to the morality, security and order of the society was followed seriously by the Ottoman Government and tried to be prevented causing great problems. It was just one of these issues in prostitution and prostitutes. The religious and moral structure of the society played a major role in the approach to prostitution and prostitutes. In other words, matters of prostitution and prostitution, which are contrary to religious and moral teachings, were subjects where society was very sensitive. These issues have even caused great events in the Ottoman Empire. In this context, the primary duties of state officials are to ensure the order and order by showing the necessary sensitivity to the 
beliefs and values of the country. However, in the 19th century, relations with western states, wars, economic crisis caused moral deterioration in Ottoman society and administrators, government officials abused their duties and powers in order to earn more money, leading to increased prostitution and many more moral problems, unrest in society, disorder and complaints. In this study, how the civil and military officers in the Ottoman Empire misused their duties and powers by establishing relations with prostitutes, Some complaints received by the Ottoman Government are dealt with. A brief assessment of prostitution and prostitute issues, in which the officers were involved, is tried to be made in the Ottoman Empire.

Keywords: Civil Servants, Prostitution, Prostitute, Morality, Ottoman Empire

\section{Giriş}

"Sarı Bal kasabanın felaketiydi. İşsiz, eğlencesiz, ücra beldenin ahalisi para sarf etmek ihtiyacı duydukları zaman içer içer, Sarı Bal'ın kapısını çalarlardı. Yerliden, yolcudan, memurdan her çeşit müşterisi vardı. Bir mal müdürü, Sarı Bal'ın uğruna kasasında açık vererek perişan olmamış mıydı? Şimdi Akka'da kalabentti, ahbaplarına gönderdiği mektuplarda hala onu soruyor, onun hatırasını kaydediyordu. Camiikebir'in o azametli sofu imamını bile gece burada bastırıvermişlerdi. Lakin şimdiki kaymakam sert davranıyordu. Polise şiddetli emirler vermiş, içeride yakaladığınızı tıkın hapse! demişti. Galiba geceleri kendisi de devre çıkıyordu ki geç vakit, bu mahalleden, yüzü sarılı geçtiğini, hatta Sarı Bal'ın evi etrafında dolaştığını görmüşlerdi. Bir akşam eşraftan Külahçızade Hilmi Ağa ve arkadaşları, Sarı Bal'ın kapısına dayanır, eğlencelerine burada devam etmek isterler. Kap1 uzun çalışlardan sonra açılır. İçki sofraları kurulur, çalgılar çengiler derken kasabanın komiseri eve baskın düzenler. Gizlenenler olmuş mudur diye evin her tarafı aranır. Sarı Bal'ın iki oğlu olmasına rağmen yerde yorganın altında dört kafanın olması şüphe uyandırır. Yorgan kaldırılır ve altında Sarı Bal hususunda sert emirler yağdıran kaymakamın gizlendiği görülür. Bu hadiseden ötürü ertesi gün kaymakam istifasını verir." 1

Ömrünün 22 yılını sürgünde geçirmiş olan Refik Halid Karay², sürgün yıllarında bulunduğu Çorum, Ankara gibi Anadolu'nun çeşitli bölgelerindeki kültürü, coğrafyayı ve insanların öykülerini, "Memleket Hikâyeleri”" eserinde derinlemesine anlatmıştır. Karay’ın 1916 yılında Çorum'da kaleme aldığı yukarıda kısa bir özetini verdiğimiz "Sarı Bal" hikâyesi de bunlardan biridir. Karay, "Sarı Bal" hikâyesiyle Osmanlı Anadolu'sunda devlet, toplum ve ahlak ilişkisini ve bu bağlamda toplumdaki yozlaşmayı, ahlaki çöküntüyü, memur ve din adamlarının vazifeleriyle ters düşen uygunsuz hal ve hareketlerini okuyucunun dikkatine sunmuştur. ${ }^{3}$ Karay'ın "Yatık Emine" adlı hikâyesi de Sarı Bal'dan pek farklı değildir. Emine, Ankara merkezinde sürekli sorunlara sebebiyet verdiğinden islah olunması amaciyla Haymana kasabasına sürülür. Sürüldügü kasabada toplumsal baskı ve dışlanmaya maruz kalan Emine, önce işinden atılır sonra boş bir evde açlığa, sefalete mahkûm edilir. Bir gün kendisinden istifade etmek için kapısına gelen iki jandarma tarafından kulübesinde ölü bulunur. Jandarmaların, "Yetişemedik be gebermiş!" sözleri ve Emine'nin cansız bedeni üzerine dahi kirli düşünceler içerisinde olmaları, aslında ahlaki çöküntünün göstergesidir. ${ }^{4}$

\footnotetext{
${ }^{1}$ Refik Halid Karay, Memleket Hikâyeleri, İnk1lâp Yayınları, İstanbul 2019, s.69-79.

${ }^{2}$ Tarih ve Toplum, “Türk Ansiklopedisi'nde Refik Halid Karay “, İletișim Yayınları, S.13, 1985, s.10.

${ }^{3}$ Ramazan Kılıçarslan, "Refik Halit Karay'ın Sarı Bal Adlı Hikâyesi Üzerine Bir Tahlil Denemesi”, Uşak Üniversitesi Sosyal Bilimler Dergisi, C.8, S.4, 2015, s.176-180.

${ }^{4}$ Karay, age, s.7-37; Yusuf Köşeli, "Evrensel Bir Tema Olarak Düşmüş Kadın: Fantine, Marta El-Bânî ve Yatık Emine", Tarih Okulu Dergisi, C.7, S.20, s.425-426.
} 
Her iki hikâyede de olaylar, bu yola nasıl düştükleri hakkında bilgi verilmeyen Sarı Bal ve Yatık Emine isimli fahişelerin etrafında gerçekleşir. Bu hikâyelerin gerçekliği tartışmalı olsa da, Osmanlı Devleti'nin adli ve idari mercilerine farklı zamanlarda intikal etmiş bazı resmi evrak ve arzuhallerin, benzer olayları içermesi son derece dikkat celbeden önemli bir husustur. Ülkenin emniyet, asayiş ve idaresinden sorumlu olanların, yetkilerini kötüye kullanarak, umumhanelere ve fahişelere aracılık etmeleri, münasebetler kurmaları ve hatta zorla kadınları bu yola sürüklemeleri, Osmanlı'nın son dönemlerinde merkez ve taşrada giderek yaygınlaşan bir sorun haline gelmiştir. ${ }^{5} \mathrm{Bu}$ bağlamda devletin farklı mercilerine merkez ve taşradan farklı tarihlerde gelen şikâyetler, gösteriyor ki Karay'ın hikâyeleri gerçekten uzak değil aksine yaşanmış veya yaşanmış olma ihtimali yüksek Osmanlı taşrasının hikâyeleridir.

Karay'ın "Sarı Bal” hikâyesindeki kaymakam, fuhuş ve fahişeler hususunda sergilediği sert tutumla ahlak konusunda aslında ne kadar hassas olduğunu kasaba halkına göstererek gözleri üzerinden çekmeye çalışmıştır. Gece çöktügünde ise yasakladığı fahişenin evine gidip eğlenmiştir. 1862 yılında Meclis-i Vâlâ'ya intikal etmiş Pravadi Kazası'nın Müdürü Abdülatif' in davası, "Sarı Bal" hikâyesindeki kaymakamın durumuyla oldukça benzerlik göstermektedir. Olay şu şekilde meydana gelmiştir;

Şumnu Sancăğ'na tabi Pravadi Kazası'ndan Selim Çavuş'a, bir Hıristiyan evinde birkaç fahişenin olduğuna dair haber verilmesi üzerine çavuş, emrindeki askerleriyle birlikte evi basmış ancak evde sadece fahişeleri değil Pravadi Kazası'nın Müdürü Abdüllatif'i de basmıştı. Aslinda fahişeleri evine çağıranda yine kendisiydi. Korkuya kapılan Müdür, askere silah doğrultarak çavuşu sol bacağından yaralamış ve çavuş aldı̆̆ yaradan dolayı yolda ölmek üzereyken köy ahalisi tarafindan kurtarlmıştt. Meselenin tahkikatı ve olaya müdahil olanların mahkemelerinin yapllması için Şumnu'ya götürüldükleri esnada Müdür firar etmişti. Bu yüzden mahkemeleri yapllamamıştı. Müdür'ün derhal yakalanarak mahkemelerinin görülmesi hususunda Silistre Valisi'ne emir gönderilmişstir. ${ }^{6}$

Bu çalışmada, devletin çeşitli kademelerinde görev yapan memurların, toplum ahlakına aykırı görülmesine rağmen fahişelerle münasebet kurmaları, görevlerini suiistimal ederek fuhuş ve fahişlere aracılık etmeleri, kadınları nasıl ve ne şekilde fahişelik yapmaya zorladıkları, fahişe olarak nitelendirilen kadınlara nasıl baskı uygulayarak onları suça bulaştırdıkları ve hatta onları nasıl öldürdükleri, merkezi hükümetin ilgili dairelerine farklı zamanlarda intikal etmiş bazı vakalar üzerinden irdeleyerek fuhuş ve fahişe meselelerinde bazı devlet memurlarının sergilediği gayri ahlaki tutum ve davranışları incelemeyi amaçladık. Osmanlı arşivinden temin edilen fuhuş ve fahişelerle ilgili vakaları içeren birkaç belgenin tarihleri olan 1833-1922 yıllarıyla sınırlandırılan bu konunun daha kapsamlı bir araştırmayla incelenmesi gerektiği kanaatindeyiz. Bu çalışmada, spesifik birkaç vaka üzerinden kısa bir değerlendirme yaparak, daha sonra yapılacak olan kapsamlı araştırma ve çalışmalara katkı sunmayı hedefledik.

Osmanlı arşiv belgelerinden istifade edilerek fuhuş ve fahişeler üzerine yapılmış bazı çalışmalar da mevcuttur. Ancak devlet görevlilerinin fuhuş ve fahişelerle olan münasebetleri hususunda daha fazla örnek vaka içeren bir çalışma yapılmadığı kanaatindeyiz. Fikret Yılmaz, "Zina Fuhuş Arasında Kalanlar, Fahişe Subaşıya Karşı", isimli çalışmasında mahkemeye intikal etmiş bir fahişenin dava sürecini ve subaşıya karşı adalet arayışını incelemiştir.Yılmaz, farklı vakalardan ziyade bir vaka üzerinden bu konuya değinmiştir. ${ }^{7}$ Kezban Acar ise "Osmanlı Devleti’nin Son Yüzyılında Fuhşu Önleme Çabalarına Dair Bazı Tespitler (1810'lar-1910’lar)”

\footnotetext{
${ }^{5}$ Başkanlık Osmanlı Arşivi, Rumeli Müfettişliği Kosova Evrakı ( BOA., TFR.I..KV.. ): 210 /20945, 11 Ramazan 1326 (07 Ekim 1908); BOA., Dahiliye Mektubi Kalemi (DH.MKT.): 1101 /78, 27 Cemazeyilevvel 1324 (19 Temmuz 1906).

${ }^{6}$ BOA, Sadaret Mektubi Kalemi Umum Vilayet (A.\}MKT.UM..): 533/70, 17 Recep 1278 (18 Ocak 1862).

${ }^{7}$ Fikret Yılmaz, "Zina Fuhuş Arasında Kalanlar, Fahişe Subaşıya Karşı”, Toplumsal Tarih, Nisan 2012, s.22-30.
} 
isimli çalışmasında bir alt başlık altında, devlet görevlilerinin fuhuş ve fahişelerle münasebet kurarak nasıl görevlerini suiistimal ettiklerini birkaç vaka üzerinden incelemiştir. ${ }^{8}$ Osmanlı siyasi ve ekonomik tarihi üzerine yapılan araştırmalar kadar sosyal yapısı üzerine yapılan ve yapılacak olan araştırmalar da büyük bir öneme haizdir. Ancak devlet-toplum ilişkisi üzerine yapılan çalışmalarda ahlak ve mahremiyet kaygılarıyla fuhuş, zina, ırza tecavüz ve fiil-i livata gibi bazı konular arka plana itilmekte, ya yüzeysel ya da hiçbir şekilde ele alınmamaktadır. Nitekim bir devletin tarihi her boyutuyla ele alınması gerektiği düşüncesindeyiz.

\section{Bazı Memurların Fuhuş ve Fahişelerle Olan Münasebetleri ve Haklarında Hükümete İntikal Eden Şikâyetler}

Toplumlardaki ahlaki çöküntünün ve yozlaşmanın sebep ve sonuçlarından biri olarak fuhuş ${ }^{9}$ ve fahişeler ${ }^{10}$ gösterilmektedir. Birçok ahlaki sorunun müsebbibi olarak görülen umumhaneler ve fahişelerle ilgili toplumda artan şikâyetler üzerine devletler bazı sert tedbir ve cezalar uygulamak zorunda kalmaktadır. Osmanlı Devleti de umumi ahlaka aykırı davranışlar olarak nitelendirdiği fuhşu önlemeye yönelik zaman zaman bazı sert tedbirler almış ve cezai yaptırımlarda bulunmuştur. İslam ve Osmanlı ceza hukukunda ${ }^{11}$ fuhuş ve zina kavramları arasında kesin bir ayrım olmayıp her ikisi de evlilik dışı cinsel münasebet olarak nitelendirildiği için zina suçuna verilen cezalar aynı şekilde fuhşa da verilmiştir. ${ }^{12}$ İslam hukukuna göre tespiti zor olan zina suçuna, Osmanlı Devleti, recm gibi cezaları tatbik etmekten mümkün olduğunca kaçınarak, örfi kanunların hükümlerine uygun olarak para ve sürgün gibi cezalar uygulamıştır. ${ }^{13}$ Ancak bazı dönemlerde fuhuş yapan ve yaptıranların asılarak veya suda boğdurularak idam ettirildiği de olmuştur. ${ }^{14}$

\footnotetext{
${ }^{8}$ Kezban Acar, “Osmanlı Devleti'nin Son Yüzyılında Fuhşu Önleme Çabalarına Dair Bazı Tespitler (1810'lar1910'lar)” History Studies, Cilt:10, Sayı:9, 2018, s.1-19.

${ }^{9}$ Fuhuş, kelime ve terim olarak İslam dininde daha geniş kullanım alanı bulunmakla birlikte fuhuş, para veya başka bir karşı1lı gözeterek karşı cinslerin veya hemcinslerin evlilik dışı cinsel münasebette bulunması olarak tanımlanabilir. Günay Tümer, ’Fuhuş", DİA, C. 13, Türkiye Diyanet Vakfı Yayınları, İstanbul 1996, s.209.

${ }^{10}$ Fahișe kelimesi, sözlükte edep ve terbiyeye aykırı fiil ve davranıș, zina olarak tanımlanan fuhuş kelimesinden türemiştir. Osmanlı'da fahişe kelimesi dışında ayrıca iffetsiz, namussuz kadın anlamındaki "âlufte" ve aynı anlama gelen "aşüfte" kelimeleri de kullanılmıştır. Arşiv belgelerinde ise sıklıkla âlufte sözcüğünün kullanıldığı görülmektedir. Kuran' da kınanan ve yasaklanan, hayâsızlık anlamındaki fahşa/fahişe kelimeleri birçok ayette zina manasında geçmektedir. Şemsettin Sami, Kâmûs-ıTürk̂, Çağnı Yayınları, İstanbul 2007, s.983; Ferit Devellioğlu, Osmanlıca-Türkçe Ansiklopedik Lûgat, Aydın Kitabevi, Ankara 2012, s.33; Hüseyin Esen, “ Zina”, Türkiye Diyanet Vakfı Yayınları, C. XLIV, İstanbul 2013, s.440.

${ }^{11}$ Bir İslam devleti olan Osmanlı, İslam hukukunun büyük bir kısmını aynen kabul ederek, hakkında açıça hüküm belirtilen alanlardaki Hanefi mezhebine ait görüşleri, uygulamalarda esas almıştır. Bkz. Abdülmecit Mutaf, "Teorik ve Pratik Olarak Osmanlı'da Recm Cezası: Bazı Batı Anadolu Şehirlerindeki Uygulamalar”, Turkish Studies, C.3, S.4, 2008, s.576-578.

${ }^{12}$ İslam ceza hukukunda, hadd suçları kapsamında yer alan zina için öngörülen ceza, evliyse recm (taşlanarak ölme), bekârsa yüz sopa ve sürgündür. Hadd suçlarında cezanın uygulanması için suçun kesin bir şekilde tespit edilmesi önem arz etmekte ve en ufak şüpheye yer yoktur. Şüpheye mahal verecek bir durum söz konusu olursa hadd cezas1 düşer. Bkz. Coşkun Üçok, "Osmanlı Kanunnamelerinde İslam Ceza Hukukuna Aykırı Hükümler", Ankara Üniversitesi Hukuk Fakültesi Mecmuast, C.3, S.1, 1946, s.132; Ekrem Buğra Ekinci, İslam Hukuku Umumi ve Hususi Hükümler, Arı Sanat Yayınları, İstanbul 2016, s.292-293.

Orlin Sabev, “Ahlakın arka Sokakları: 18. Yüzyıl Osmanlı İstanbul'unda Fuhuş ve Ceza”, Osmanlı İstanbul'u IV, s.626.

${ }^{13}$ Osman Köse, "XVIII. Yüzyıl Sonları Rus ve Avusturya Savaşları Esnasında Osmanlı Devletinde Bir Uygulama: İstanbul'da İçki ve Fuhuş Yasağı", Turkish Studies, C.2, S.1, 2007, s.106.

${ }^{14} 18$. yüzyılda uzun süren Osmanlı-Rus savaşları ve ekonomik sıkıntılar nedeniyle fuhuş daha da artmış, özellikle III. Selim döneminde içki ve fuhşun yaygınlaşması üzerine bazı sert tedbirler alınmıştır. Fuhuş yaptıkları gerekçesiyle tutuklanan fahişelerden beş tanesi ibreti âlem için bir gece Ağa Kapısı civarında İmam Önü’ye getirilerek boğdurulup üçü İstanbul'un merkezinde, biri Üsküdar'da diğeri ise Kasımpaşa'da astırılmıştır. Bu hadiseden sonra tutuklu bazı fahişeler, tövbe edip bu işi bırakmış bazıları ise sürgün edilmişti. Ancak alınan bu 
Osmanlı, fuhşa özellikle fuhşa aracılık edenlere ilk kanunnamelerden itibaren bazı cezalar öngörmüş ve cezalar, fahişelerden ziyade onları kandıran ve fuhşa iten aracılara kesilmiştir. ${ }^{15}$ Bu bağlamda Fatih Kanunnamesi'nde birinci faslı zina suçuna ayrılarak pezevenlik edene para cezası öngörülürken, Aydın-Eli Siyasetnamesi'nde (1493) "pezevenlik daima âdeti ve sanatı ola, burnı kesile ve illa eşeğe bindürüp teşhir oluna..." şeklinde, II. Beyazıt Kanunnamesi'nde, I. Selim dönemi Manisa Sancağ1 Siyasetnamesi'nde ve Kanuni Sultan Süleyman Kanunnamesi'nde ise "pezevenlik edenin alnını dağ edeler", şeklinde fuhşa aracılık edenlere bedensel cezalar öngörülmüştür. ${ }^{16}$ Ayrıca omuzlarında birer mumla, çıplak bir vaziyette ve yüzleri karalanmış biçimde dolaşmak gibi aşağılayıcı cezalar da verilerek suçu işleyen kişiyi toplumda teşhir etmek suretiyle caydırıcı cezai uygulamalara da gidilmiştir. ${ }^{17}$

19. yüzy1lda Rusya ile olan savaşlar, iç karışıklıklar, isyanlar, zaten kötü durumda olan Osmanlı ekonomisinin giderek bozulmasına, işsizliğin, fakirliğin ve ahlaki sorunların giderek artmasına neden olmuştur. Savaşın neden olduğu fakirlik, insanları değer yargılarından koparmakta, İstanbul başta olmak üzere ülkenin neredeyse her yerinde ahlaki sorunların artmasına sebep olmaktaydı. Ülkenin içerisinde olduğu bu zor dönemlerde birkaç kuruş daha fazla kazanmak gayesiyle memurlar, türlü yolsuzluğa başvurmakta, devlet memuruna yakışmayan hal ve hareket içerisinde bulunmaktaydılar. ${ }^{18}$ Toplumun asayiş, emniyet ve nizamından sorumlu olan askeriyeden ve mülkiyeden memurlar, fuhşu meslek haline getiren kadınlara aracılık etmek, onların elindeki paraya ortak olmak, sefalete duçar olan kadınların bu halinden istifade ederek onları fuhşa zorlayıp ellerindeki paraya el koymak, fahişelere piyasa yaratarak ticaretlerini yapmak, fuhuşla ilgili şikâyetleri aldıkları rüşvet karşıllı̆ında görmezden

tedbirler fahişeliği önlememiş, kerhane/umumhanelerde, İstanbul'un değişik sahil semtlerindeki iskelelerde ve bekâr odalarında fahişeler bu işi yapmaya devam etmişlerdir. Bkz. Engin Kırlı, “ Tanzimat Sonrası Fuhuş Hadisesine Yaklaşımda Yaşanan Değişim”, Süleyman Demirel Üniversitesi Sosyal Bilimler Enstitüsü Dergisi, C.2, S.12, 2012, s.43; Aydın Yetkin, "II. Meşrutiyet Dönemi'nde Toplumsal Ahlak Bunalımı: Fuhuş Meselesi”, Tarihin Peşinde Uluslararası Tarih ve Sosyal Araştırmalar Dergisi, S.6, 2011, s.25; Onur Gezer, "Çizginin Dışındakiler: Osmanlı İstanbul'unun Aykırı Bekarları ve Bekar Girer Melek Girmez Odaları”, Osmanlı İstanbul'u II.; Sabev, agm, s.626634.

${ }^{15}$ Kezban Acar, “Osmanlı Devleti'nin Son Yüzyılında Fuhşu Önleme Çabalarına Dair Bazı Tespitler (1810lar1910lar)", History Studies, C.10, S.9, Aralık 2018, s.3.

${ }^{16}$ Cihan Osmanağaoğlu, "Klasik Dönem Osmanlı Hukukunda Zina Suçu ve Cezası”, İ̈HHFM Dergisi, C.LXVI, S.1, 2008, s.133-134.

${ }^{17}$ Acar, agm, s.3-4.

${ }^{18}$ Kumar, içki, fuhuş, devlet görevlilerinde en fazla görülen gayri ahlaki alışkanlık ve davranışların başında gelmekteydi. Fahişlerle münasebet kurup içkili ortamlarda zaman geçirmek, fahişeleri kapatmaları yapmak veya fuhuş için özel evler açtırarak, buralarda gizlice birilerini ağırlama, kumar oynatma ve daha bunlar gibi birçok birbiriyle ilişkili ahlakdışı işlere karışmış, haklarında şikâyet bulunan devlet görevlileri vardı. Bu hususta devlete intikal etmiş birkaç şikâyeti örnek verebiliriz. 1899 yılında Jandarma Süvari Mülazımı Azmi Efendi, vazifesini suiistimal edip fahişe Rum bir kadınla birlikte gece dolaşmaktayken tutuklanmıştı. Tayin edildiği bölgeye geldiğinden beri Azmi Efendi'nin vazifesini yerine getirmediği, alkol bağımlısı olduğu ve geceleri devriye geziyorum deyip bir fahişe Rum kadınıyla gezdiği ifade edilerek hakkında şikâyette bulunulmuş ve Azmi Efendi'nin cezalandırılarak buralardan derhal uzaklaştırılması istenmişti. BOA., Dahiliye Nezareti Şifre Kalemi (DH.ŞFR.): 243/ 65, 29 Teşrinisani 1315 (11 Aralık 1899). Kemal isimli bir devlet memurunun ise kiraladığı evlerde fuhuş yaptırdığı bildirilmişti. Cemiyet-i rüsumiye azasından Kemal Beyefendi'nin Küçükçekmece Köyü’nde inşa ettirmiş olduğu Köşk ile Yeşilköy’de kiraladığı diğer üç eve bazı fahişeler çağırarak ahlaka aykırı hal ve harekette bulunduğu haber alınması üzerine merkezi hükümet, ahlak dışı olayların hemen önünün alınması ve tekrar bu gibi şeylerin yaşanmaması için gerekli tedbirlerin alınarak Kemal Beyefendi’nin orada bulunduğu süre zarfında gözetim altında tutulmasını bölge kaymakamlığından istemiştir. BOA., Yıldız Tasnifi Perakende Evrakı Mütenevvi Maruzat Evrakı,(Y..MTV.): 47 /185, 25 Cemaziyelahir 1308 (05 Şubat 1891). Kumar oynattığı ve fuhuş yaptırdığı bildirilen bir diğer devlet görevlisi ise Muzıka-yi Hümâyun zabıtalarından Tahsin Bey idi. BOA., Dahiliye Nezareti Emniyyeti Umumiye Müdiriyyeti Kısm-1 Adli Kalemi, (DH.EUM.KADL.): 4 /39, 13 Muharrem 1329 (14 Ocak 1911). 
gelmek, evlere gizlice fahişe alarak eğlence düzenlemek ve daha bunlara benzer birçok mesleki ahlaka aykırı hal ve harekette bulunarak fuhuşun yaygınlaşmasına neden olmaktaydılar. ${ }^{19}$

Devlet görevlilerinin, içki ve sefahate düşerek devletin kanun ve nizamına aykırı olan birçok suçu ve suçluyu rüşvet karşılığında hükümetten gizlemeleri, suçluların hamileri olmaları ve hatta yapılan ahlaksız işlere parasal yönden ortak olmaları, tarihin her döneminde her toplumda görülen vakalardı. Osmanlı Devleti'nde de rüşvet, yolsuzluk, sahtekârlık gibi gayri ahlaki yollara sapan memurlar olmuştur. Özellikle devletin siyasi, sosyal ve ekonomik sorunlarla baş etmekte zorlandığ 1 ve otoritesinin zayıfladığ 1 dönemlerde merkez ve taşrada devlet memurları hakkında şikâyetlerin de arttığı görülmüştür. Ülkenin her tarafından umumhaneler, fahişeler ve gayri ahlaki işlere bulaşmış memurlar hakkında şikâyetler merkezi hükümete intikal etmiş olsa da Osmanlı'nın ithalat-ihracata açık ve yabancı nüfusun daha fazla olduğu liman şehirlerinde daha fazla arzuhaller gönderilmişti. Bu liman şehirlerinden biri de İzmir idi. ${ }^{20}$

1893 yılında "İslamiyet ve asayiş nazarından gayet mühimdir" başlığıyla İzmir Başkomiseri ve Alaybeyi'nin bilgisi ve onayı dâhilinde İzmir'de meydana gelen fuhuş, kumar, hırsılık, rüşvet gibi umumi ahlaka aykırı durumları bildiren bir yazı, Yıldız Sarayı'na gönderilmişti. Belgede yazılanlar kısaca şu şekildeydi;

"İzmir'de bir vukuat meydana gelse ispat olunması zordur, şöyle ki İzmir Alaybeyi ve Başkomiseri hesaplarına daha fazla para çekmek için her kötülüğ̈̈ yapmaktan geri durmuyorlar. Karataş Mahallesi'nde mumhane yanında ve Başkomiser'in evinin yakınlarında Bahur isimli Yahudi, bir hamam yaptırmıştır. Dikkat çekmemek için bu hamama bir evin içinden girilmektedir. Amaç evin içerisinden Müslüman kadınları hamama sokup Yahudi ve Hıristiyan gençlerle fuhuş yaptırmaktır. Bunun haricinde Birinci Kordon üzerinde bulunan Fransız Hoteli'nin bir kısmı umumhaneye çevrilmiştir. Zabıta ve diğer memurlar, kapıda "Fransız Hoteli" yazılı olan levhayı görerek aileleriyle hotele misafir olmakta, bir umumhanede oldukların bilmemektedirler. Hâlbuki bu hotelin biri Birinci Kordon diğeri İkinci Kordon üzerinden iki kapısı bulunmaktadır ve fuhuş için ikinci kapıdan girilmektedir. Ancak Müslüman kadınların büyük bir kısmı bir yolcu gibi gündüz birinci kapıdan girip ikinci kısma geçmektedirler. Hatta bir Müslüman kadının fuhşa mahsus olan kapıdan girdiğine şahit olunmuştur. Kadının çıkması beklenmiş ancak çıkmayınca bir çocuk oraya gözetlemesi için bırakılmıştı. Gece saat ikide kadının oradan çıkıp çıkmadığı sorulduğunda, kadının hala içeride bulunduğu ve birkaç şapkalı Hıristiyan'ın da içeriye girdiği gözlemlenmişti. Bunun üzerine hemen o civarda bulunan pasaporthaneye girip oralarin güvenliğinden sorumlu olan polise, bu durum ihbar edilmişti. Ancak polis, "bizde biliyoruz fakat bizim elimizden bir şey gelmez, Başkomiser Efendi ile Alaybey'ine söyleyiniz”, cevabını vermiştir. Aslında polis, bu gibi uygunsuzlukların Başkomiser ile Alaybey'in izniyle vuku bulduğunu ima etmiştir. Polisin elinden bir şey gelmeyeceği anlaşılınca mesele, vilayetin vekiline ve defterdar efendiye bir yazlyla ihbar ve şikâyet edilmişti. İzmir'de umumhanelere mahsus olmak üzere Sakızlılar Mahallesi tahsis edilmişken İmir'in en temiz yerinde bulunan Kordon'da birkaç umumhane açılmış ve bunlar her ay polis dairesine birkaç akçe vermekle mükellef kılınmıştır. Her ne kadar bunların men edilmesi hususunda o civarın sakinleri tarafindan şikâyet dilekçesi verilmişse de ehemmiyet verilmemiştir. Müslüman kadınların, Hıristiyan ve Yahudi erkeklerle fuhuş yapmalarına mani olunmazsa Müslüman ahalinin ayaklanarak büyük hadiselerin yaşanma

\footnotetext{
${ }^{19}$ Askerin fütursuzca davranışları bazen büyük bir ayaklanmaya sebebiyet verebilmekteydi. Kars’ta askeriyeden Mehmet Çavuş sarhoş olduğu halde birilerinin kışkırtmasıyla mahalleden bir fahişenin yanına giderek kılıç ile kadının bir parmağını keserek kavga çıkmasına neden olmuştu. Olaylardan haberi olan Binbaşı Mustafa, Çavuş'u hapse attırmışsa da birileri ahaliyi galeyana getirerek valinin sarayına hücum etmişler ve yolda karşılaştıkları askerlerden altı kişiyi yaralamış, Binbaşıyı dahi iki yerinden yaralamışlardı. Çavuş’u hapisten alarak meydanda katletmişlerdi. BOA., Hatt-1 Hümayun (HAT.): 301 / 17897, 01 Zilhicce 1248 (21 Nisan 1833).

${ }^{20}$ 16. yüzyıldan 20. Yüzyılın başlarına kadar bir liman şehri olarak İzmir'in geçirdiği değişim için bkz. Edhem Eldem, Daniel Goffmann \& Bruce Masters, Doğu İle Batı Arasında Osmanlı Kenti Halep İzmir ve İstanbul, Çev: Sermet Yalçın, Türkiye İş Bankası Kültür Yayınları, İstanbul 2017, s. 95-164.
} 
ihtimali yüksek. Başkomiser bazı geceler, Maltiz Çarşısı'ndaki bir umumhaneye gidip eğlenmektedir. Bazl mahallelerde Başkomiser'e on beş lira vermek üzere alenen kumar oynanmaktadır. Ayadimitri Kilisesi'nin karşısında Yunan tebaasından Niko'nun evinde ve Sakızlılar Mahallesi'nde İstanbullu Hacı'nın kahvehanesinde oynatılan kumarda her gece insanlar soyulmaktadır. Bir de hırsızlar, her sabah Başkomiser'in evine gidip onunla görüşerek kendisine para vermektedirler. Ĕ̆er evinin önüne bu durumu gizlice gözetlemesi için bir memur konulursa tüm olan bitene şahit olacaktır. Başkomiser, maiyetinde bulunan polislere karşı anlayışlı olduğundan polisler dahi bundan istifade ederek mahalle aralarında birer kapatmaları bulunduğu gibi yapmadıkları rezalet kalmamıştır. Haklarında komiserliğe yapılan şikâyetlerde neticesiz kalmaktadır. Hatta birer bahaneyle adam soymak, ırza tasallut etmek gibi suçlara cüret ettikleri için halk bunlardan nefret etmektedir. "21

Yıldız Sarayı'na gönderilmiş jurnal niteliği taşıyan bu yazıda, İzmir'in asayiş ve emniyetinden birinci derecede sorumlu olan Başkomiser ve maiyetindeki polislerin, para karşılığında her türlü gayri ahlaki işlere göz yumdukları, İzmir'deki ahlaksızlığın artmasında Başkomiser'in büyük payı olduğu, Müslüman kadınların, otellerde Hıristiyan ve Yahudi erkeklerle fuhuş yaptıkları, sadece bir semtte umumhane işletilmesine müsaade edilmesine rağmen Kordon'da dahi umumhanelerin olduğu ve en önemlisi eğer derhal hükümet duruma müdahale etmez ve nizam sağlanmazsa halkın ayaklanacağı belirtilmiştir. 19. yüzyılın ikinci yarısından itibaren umumhanelerin ve fahişelerin sayısında artış meydana gelmiş, İstanbul başta olmak üzere İzmir gibi yabancı nüfusun yoğun olduğu şehirlerde umumhaneler dişında ayrıca gizli fuhuş yerleri de işletilmişti. Hükümet, artan fuhşun önüne geçmek için bir dizi tedbir almış, gayri resmi işletilmekte olan umumhaneleri denetim altında tutmaya çalışmış, belirli semtlerde olmak şartıyla açılmalarına göz yummuştur. Umumhanelerdeki kadınların muayene ve tedavi edilmeleri uygun görülerek $1884^{\prime}$ te bir talimatname ile İstanbul'daki umumhanenin muayene ve teftişi karara bağlanmıştır. Böylelikle gayri resmi olan umumhaneler ruhsata bağlanarak resmi bir hüviyete sahip olmuşlard. ${ }^{22}$ Yukarıdaki arzuhalin içeriğinden de anlaşıldığı üzere İzmir'de umumhanelerin işletilmesine müsaade edildiği semt Sakız Mahallesi olmasına rağmen, öncelikli görevleri şehrin güvenliğini ve düzenini sağlamak olan kolluk kuvvetleri, merkezden gelen emirlere riayet etmeyerek umumhaneleri Sakız gibi sadece belirli semtlerde sınırlı tutmaları gerekirken rüşvet karş1lığında İzmir'in en kalabalık yerlerinde dahi fuhşa göz yummuşlardı. En üst rütbedeki kişinin bilgisi ve onayı dâhilinde olması ise sorunun ciddi bir boyutta olduğunu göstermektedir. Toplumun inanç ve ahlakına aykırı olan bu hareketlerin devlet görevlileri tarafından engelleneceğine aksine desteklenmesi, halkın devlete olan güvenini kırmakta olduğu, böyle devam ederse halkın ayaklanacağ1, arzuhalde ifade edilmiştir. Müslüman bir kadının Hıristiyan veya Yahudi bir erkekle cinsi münasebette bulunması, Osmanlı toplumunda dini öğreti ve hassasiyete aykırı bir hareketti. ${ }^{23}$

Polis, jandarma ve zaptiye gibi toplumun huzur ve asayişinden sorumlu olan kolluk kuvvetlerindeki ahlaki bozulma, fuhuş ve kadın ticaretinin artması gibi toplumda ciddi sorunlara yol açmıştır. Devlete gönderilmiş bazı şikâyet evraklarında, fuhuş dâhil birçok asayiş sorunun müsebbibi olarak askeriyeye mensup devlet görevlileri gösterilmiştir. Polislerin kadınları tehditlerle nasıl zorla fahişelik yapmaya zorladıklarıyla ilgili 1892 yılında merkezi hükümete intikal eden, "Gayet mühim bir maddedir", başlığını taşıyan bir diğer yazının içeriği ise şu şekildeydi;

\footnotetext{
${ }^{21}$ BOA., Y1ldı Tasnifi Perakende Arzuhaller ve Jurnaller, (Y..PRK.AZJ.): 24/48, 28 Zilkade 1310 (13 Haziran 1893).

${ }^{22}$ Yetkin, agm, s.26-28.

231860 yılında Beyrut'ta Hıristiyan bir erkekle Müslüman bir fahişe zina yaparken basılmaları, günlerce süren bastırılması zor çatışma ve ayaklanmalara neden olmuştu. BOA., A.\}MKT.UM.. 414/3, 22 Zilhicce 1276 (11 Temmuz 1860).
} 
Osmanlı Devleti'nde Memurların Müdahil Olduğu Bazı Fuhuş ve Fahişe Meseleleri Üzerine...

“Osmanlı Devleti'nde bu dönemde zaptiye yoldan çıkmış, herkes mal, can ve ırzının muhafazasından emin değil ve ahali üzüntü içerisinde kalmıştır. Bir memleketin asayiş ve huzuru için o memleketin güvenliğinden sorumlu olanların namus ve hamiyet sahibi olmalar gerekmektedir. Bu vasıflara sahip olmayan ipsiz sapsiz ne idüğ̈ belirsiz adamlar ile askeri nizamiyede terbiyeleri mümkün olmayıp ihraç edilenler, polis ve komiserliğe kaylt olup zaptiyede çoğalarak her tarafi istila etmişlerdir. İşte zaptiyeden beklenen güzel işler ve idarenin aksine arz edilen ve edilecek olan fenalıklar yüzünden bunlar halkta nefrete yol açmıştır. Cinayet, hırsızlık, ırz ve namusa yönelik suçlar, bu memurların yüzünden çoğaldıkça çoğalıyor ve daha bunlar gibi nice sorunlar polis ve komiserlerinden zulmünden dolayl yaşanmaktadır. Bunlar yüzünden bazı kadınlar fahişe olmaya mecbur bırakılmakta ve bazlları dahi günahsız olmalarına rağmen hapislerde ziyan olup gitmektedirler. Bu durumun başlıca sebebi, nazırın idaresizliğiyle beraber kendi şahsi menfaatlerine hizmet etmek için idareyi Polis Meclis Reisi Hüsnü ile polis memuru Şaban Efendi'ye ve meclis heyetine birakarak onların serbest bir şekilde zulmetmelerini sağlamasıdır. Onlar yüzünden herkesin rahat ve huzurunu kaçmıştır. Şöyle ki komiser ve polis memurlarl, görev bölgeleri dâhilinde bulunan umumhane, meyhane ve gazinolardan her ay 5-6 lira rüşvet alarak kanun ve nizama aykırı olmasına răgmen geç vakte kadar açık bıraktırarak türlü vukuatın meydana gelmesine izin vermektedirler. Ayrıca bunların büyük çoğunluğu, sivil elbise ile gezip dolaşarak gözlerine kestirdikleri hanımlara, "babalarınızdan, kardeşlerinizden veya kocalarınızdan ayrılın" diyerek tehditlerde bulunup onlarla münasebet kurmaktadırlar. Istediklerini yapmayan biçare kadınlara da iftiralarda bulunarak zorla zaptiyeye götürüp kocalarından boşatıp kadınları perişan etmektedirler. Ĕ̆ger yine istediklerini alamazlarsa tutuklayıp hapse atıp fahişe olmalarına neden olmaktadırlar. Irzlarını teslim etmeyenler hapishanelerde çürümektedirler. Ayrıca polis ve komiserler, tutukladıklarl canileri adliyeye teslim etmeyip güya "önce tahkikat yapacağız" diyerek birkaç gün hapiste tutuktan sonra para karşılı̆̆ında salıvermektedirler. Bu yüzden hırsızlık artmakta, nice ev ve dükkân soyulduğu gibi kendileri dahi firsat buldukça gece rastladıkları adamlar soymakta ve evlere dahi girerek hırsızlık yapmaktadırlar. Sonuç olarak memlekette gün ve gün artmakta olan yolsuzlukların acilen bir çaresine bakılmazsa neticesi vahim olacaktır. "24

Belgede öne sürülen iddialara göre, polisler yalanlarla iftiralarla nice yuvalar yıkıp kadınları fuhşa ve fahişeliğe sürüklemekte, isteklerine boyun eğmeyenleri ise hapse atıp heba etmekteydiler. Yukarıdaki her iki arzuhalde de benzer hususlar şikâyet edilmiş, devlet bu gidişe bir dur demezse sonuçlarının kötü olacağı ifade edilmiştir. İfadelere bakılacak olursa polis, komiser, gardiyan, zabıta, jandarma ve onların başındaki idareciler, suçu ve suçluyu engelleyeceklerine kendilerine verilen yetkileri kötüye kullanarak daha büyük sorunlara sebebiyet vermeleri, halkta büyük bir endişe ve huzursuzluğa yol açmıştır.

Görevini kötüye kullanan Gardiyan Mehmet Çavuş'un davası da bu hususa örnek teşkil etmektedir. Kadın hapishanesi gardiyanı Mehmet Çavuş, hapishaneden bazı kadınları yalan talimatlarla dışarı çıkarıp fahişeliğe sevk ettiği iddiasıyla mahkemeye çıkarılmıştı. Yapılan mahkemede Ceza Kanunu'nun 201. maddesi (her kim birilerini kandırıp fuhuş yaptırırsa bir aydan bir seneye kadar hapis cezasına çarptırılır) ${ }^{25}$ gereğince üç ay müddetle hapse mahkûm edilmiş, ancak Mehmet'in vazifesini kötüye kullanarak suç işlediği, şahitlerin ifadesiyle sabit ise de suçu, Ceza Kanunu'nun 102. maddesi hükmüne girdiği ve bu maddenin hükmü tatbik edilmesi gerekirken 201. maddenin tatbiki uygun olmayacağından, 102. maddenin birinci

\footnotetext{
${ }^{24}$ BOA., Y..PRK.AZJ. 21 /65, 23 Şaban 1309 (23 Mart 1892).

25 "Her kim zükûr (erkek) ve inasdan (kadın) genç kimseleri idlal ve iğfal (kandırma) ederek fuhşiyata tahrik ve iğra ve esbab-i husulünü teshil etmeyi itiyat ederek adab-1 umumiyeye münafi harekete cesaret eyler ise bir aydan bir seneye kadar hapis cezasına çarptırılır. Ve eğer bu suretle idlal ve iğfal kaziyesi baba yahut ana veyahut vasi olan kimselerden zuhur eder ise altı aydan bir buçuk seneye kadar hapis ile cezalandırılır." Fehminaz Çabuk, " 19. Yüzyılda Osmanlı'da Zina Suçu: Bazı Zina Davları ve Tatbik Olunan Cezalara Dair Bir Değerlendirme", Tarih Okulu Dergisi, C.12, S.XL, s.416; Acar, İsmail. "Osmanlılarda Zina Suçu ve Cezası”, Türkler, C.10, Yeni Türkiye Yayınları, Ankara 2002. s.156.
} 
fıkrası gereğince Mehmet Çavuş’un üç lira Osmani nakdi ceza, yüz kuruş mahkeme-i iptidai ve yüz yirmi buçuk kuruş masraf-1 istinaf olmak üzere toplamda iki yüz yirmi buçuk kuruş kendisinden tahsil edilerek Dâhiliye veznesine verilmesi uygun görülmüştür. ${ }^{26}$ Devletin gözetimde olan kadınların, hapishaneden çıkartılıp fuhşa sevk edilmeleri, bir noktada hapishaneler üzerindeki denetimlerin aslında sıkı olmadığını göstermektedir. Gardiyana önce hapis cezasının verilmesi sonrasında bunun nakdi cezaya çevrilmesi, cezanın suçun bir daha işlenmemesindeki caydırıcılığını kaybettirmektedir. Ayrıca vazifesini bu şekilde ahlaki olmayan bir yolda suiistimal eden birinin, suçu ispat edilmesine rağmen neden azledilmediği de ayrı bir soru işareti oluşturmaktadır.

Mehmet gibi Onbaşı Ali isimli bir askerin ise, fahişeleri Fransız kışlalarına getirip, korkutarak zorla fuhuş yaptırıp paralarına el koyduğu tespit edilmişti. Polis Fransız şubesi kumandanı Binbaşı Mösyö Strayef tarafından polis müdüriyetine yazılan tezkerede, Makriköy jandarma bölük efradından olduğu tespit edilen Onbaşı İsmail oğlu Ali’nin St. Arto Fransız Kışlası civarında bir takım fahişe kadınlarla uygun olmayan hallerde yakalandığ 1 bildirilmişti. İstanbul zabıtasının hazırladığı tahkikatta, Ali'nin bu kadınları daima Fransız kışlalarının civarına getirerek oralardaki gizli yerlerde bazı askerlerle uygun olmayan münasebetlerde bulundurduğu ve fahişelere zarar verip korkutarak zorla onlardan bir miktar para aldığı tespit edilmişti. İzmirli on sekiz yaşındaki Pakize isimli fahişe dahi itirafında bunu dile getirmişti. İstanbul Jandarma tabur kumandanlığı tarafindan yapılan tahkikatta ise Ali'nin jandarma olmayıp Makriköy İnzibat bölüğünün Zuhuratbaba'daki inzibat karakolu efradından olduğu tespit edilmiş ve hapse atılmışt1. ${ }^{27}$

Onbaşı Ali gibi askeriyeden Mülazım Mehmet Ăga da fahişelerden zorla para alarak görevini kötüye kullanan bir askerdi. Hükümete intikal eden davaya göre, Bursa Atpazarı Karakolhanesi mülazımlarından Trabzonlu Mehmet Ağa, fahişe Katırcıkızı Hatice vasıtasıyla fahişelerden tehditle para almakta ve yine aynı kişiler vasıtasıyla piyasaya kırık ve nakış altın sürmekteydi. Bununla da kalmayıp yine onlara zorla eşya satarak birçoklarını zarara uğratmıştı. İşlediği bu suçlardan dolayı Ceza Kanunname-i Hümayun'un 68. maddesi hükmüne bağlı olarak tevkif tarihinden itibaren üç sene müddetle kalebent edilmesine ve altı sene müddetle görevinden uzaklaştırılmasına ve Mehmet Ağa'ya aracilık eden Hatice'nin ise kanunnamenin 72. maddesinin hükmüne bağlı olarak hapis tarihinden itibaren bir sene müddetle tevkifine karar verilmişti. Mülazım Mehmet'in Rodos'ta kalebent edilmesi hususu gerekli yerlere yazılarak cezanın icrası için izin istenilmiştir. ${ }^{28}$

Bir askerin de evini kerhaneye çevirdiği iddia edilerek şikâyet edilmişti. Topkapı civarında Seyit Nazım Mahallesi'nde ikamet eden Tophane Alay efradından Mustafa'nın evini kerhane haline getirerek fuhuş eylemekte olduğu mahalle ahalisinden bazıları tarafindan beyan ve şikâyet edilmesi üzerine Mustafa sorguya çağırılmış ifadesi alınmıştı. Mustafa ifadesinde hanesine birtakım şahsı kabul ederek fuhuş yaptıranın kendisi değil annesinin olduğunu ve ayrıca Tophane Alayı'ndan firar ettiğini de itiraf etmişti. Firar hususunda gerekli tahkikatın yapılarak Mustafa'nın geri alayına teslim edilmesi hususunda gerekenin yapılması için Tophane-i Amire'ye yazı gönderilmiştir. ${ }^{29}$ Mustafa ifadesinde fuhuş yaptıranın annesi olduğunu söylemiş, ancak annesine bir ceza verilip verilmediğini bilmiyoruz.

\footnotetext{
${ }^{26}$ BOA, Dahiliye Hapishaneler Müdüriyeti (DH. MP.. HPS.), 89/23, 05 Zilhicce 1331 (05 Kasım 1913).

${ }^{27}$ BOA, Dahiliye Nezareti İrade-i Umumiye Müdüriyeti ( DH.İ.UM.), 19 /1, 06 Zilkade 1340 (01 Temmuz 1922).

${ }^{28}$ BOA, DH.MKT. 1535/ 90, 17 Zilhicce 1305 (25 Ağustos 1888).

${ }^{29}$ BOA, Zaptiye Nezareti Belgeleri (ZB.), 366/107, 09 Şubat 1323 (22 Şubat 1908).
} 
Evli, namuslu kadınları gözüne kestirenler olduğu gibi ${ }^{30}$ fahişelik yapan kadınlara da musallat olup rızaları olmadığı halde zorla evlerine giren devlet görevlileri de vardı. 1910 yılında fahişe olduğu söylenen Nazire isimli bir kadın, maruz kaldığı böyle bir zorbalığı arzuhalle Emniyet-i Umumiye dairesine bildirmişti. Arzuhalde yazılanlara göre, Karahisar polis Komiseri Tevfik ve Polis Ali Efendi, Nazire'nin evine gelip zorla kapıyı açtırarak içeri girmiş, içki içmişlerdi. Onları takip eden jandarmalar evi basmış, içerdeki polislerin uygunsuz hal ve hareketlerine şahit olmuşlardı. Nazire'nin ifadesi alınmış, işledikleri suçlardan dolayı kanunen cezalandırılmaları için müracaatta bulunulmuşsa da yapılan şikâyete asla itibar edilmemiştir. Polisler aynı şekilde uygunsuz hal ve harekette bulunmaya devam etmişlerdi. Hâlbuki jandarma, Tevfik ve Ali'yi Nazire'nin evinde basmış, uygunsuzluklarına şahit olmuşlardı. Nazire'nin şikâyeti üzerine hükümet, emniyet mensubu oldukları tespit edilen bu iki kişi hakkında yeniden tahkikat yapılarak tahkikat sonucuna göre haklarında kanunen gerekenin yapılması ve neticenin bildirilmesini istemiştir. ${ }^{31}$ Bir kadının fahişe olması, polislere evine zorla girip içki içme hakkını verir mi? Haklarında şikâyet olmasına rağmen polis oldukları için mi acaba suçları örtbas edildi? Diğer taraftan şikâyette bulunan fahişe bir kadın olduğu için mi şikâyete itibar edilmemişti? Yeniden yapılacak olan tahkikatın sonucuyla ilgili elimizde bir belge olmadığ 1 için kesin bir yargıya varmak pek mümkün olmamaktadır. Ancak şunu söyleyebilirz ki Nazire, kendisine reva görülen bu haksızlığa karşı susmamış, merkezi hükümette bir arzuhalle durumu bildirmiş ve adalet istemiştir. Osmanlı Devleti'nde bu ve benzeri birçok vaka da olduğu gibi fahişe olduğu söylenen kadınlar, haklarını aramaktan geri durmamış, meramlarını arzuhalle bildirerek haklarını savunmuşlardır. Fahişe olmalarından dolayı Nazire gibi polisler tarafından gayri ahlaki bir muameleye maruz bırakılan başka kadınlar da vardı. Selanik'te kendisine atılan bir iftira yüzünden polisler tarafından evi basılan ve haksız yere mağdur edilen Eleni de bu kadınlardan sadece biriydi. Bulunan bir bebek cesedinin Eleni'nin olabileceği gerekçesiyle, polisler kadını zorla birkaç defa muayene ettirmişti. Suçsuz olduğu anlaşılan Eleni, onur ve haysiyetine karşı yapılan bu muameleyi kabul etmemiş, polis memurunu şikayet etmişti. Ancak Nazire'nin olayında olduğu gibi şikayeti ciddiye alınmamış, dava örtbas edilmişti. Eleni, bu durumu kabulenmemiş, kendisine yapılan haksızlığı merkezi hükümete bir arzuhale bildirmiştir. ${ }^{32}$ Osmanlı'da ırkı, inancı, cinsiyeti, kim olduğu ve ne iş yaptığı farkedilmeksizin devletin kapısı adalet arayan herkese açıktı. Karşılarındaki devlet memuru olsa da, 1580 yılında subaşıya ve mahleliye karşı mahkemede hakkını arayıp kendini savunan fahişe $\operatorname{Sultan}^{33}$ da, 20. yüzyılın başında haksız muamelelere maruz kalan Eleni ve Nazire de bu bilinçle cesurca adalet arayışında bulunmuşlardır.

1886 yılında Çinekli Köyü komiserliğinden Beylerbeyi bölgesine teslim etmeleri için kâğıtlarıyla birlikte saat bir sıralarında dört fahişe, Polis Arapkirli Mustafa ve Jandarmadan

\footnotetext{
${ }^{30}$ Uzun süren savaşlar, açlık, yokluk yüzünden devlet görevlilerinin eşleri de fuhşa sürüklenmekteydi. Kimsesiz kadınların çaresizliğinden istifade edenler, türlü yalanlarla onları kandırıp fahişelik yaptırmaktaydılar. 1917 yılında Tokat eşrafından Salih Beyzade Mehmet Bey'in harpte bulunan askerlerin ailelerini zevcesi vasıtasıyla kandırarak fuhşa sürükleyip namuslarını payımal ettiği hakkında şikâyet alınması üzerine hemen ilgili yerlere tahkikat yapılması için emir gönderilmişti. Yapılan tahkikata göre, İşsiz güçsüz takımından olan Mehmet, ailesini ziyarete gelen çaresiz, muhtaç kadınları perde ve kapı aralıklarından karısının da yardımıyla seçip kandırmaktaydı. Bu şekilde Jandarmadan Osman Bey'in zabıtayla evli olan kızını kandırarak onla gayri meşru münasebette bulunduğu ahalinin şahit olduğu bir durum olsa da ahali, Mehmet Bey'e sadık olduğundan onun hakkında hiçbir yere bir şikâyette bulunulmamış ve dava açılmamıştı. Ayrıca karısı marifetiyle zabıta ailelerinin kandırılarak fuhşa sevk edildiği hususunun dahi işitildiği ifade edilmişti. BOA., Dahiliye Nezareti Emniyet-i Şubesi Takibat-1 Adliye Kalemi, (DH. EUM. ADL.), 32 /28, 16 Recep 1335 (08 Mayıs 1917).

${ }^{31}$ BOA., Dahiliye Nezareti Emniyet-i Umumiye Tahrirat Kalemi (DH. EUM. THR.), 44 / 5, 21 Recep 1328 (29 Temmuz 1910).

${ }^{32}$ BOA, Teftişat-1 Rumeli Evrak1-Selanik Evrakı (TFR. I. SL.), 66/6533, 13 Muharrem 1323 (20 Mart 1905).

${ }^{33}$ Yilmaz, agm., s.22-30.
}

Volume 12 
Yusuf'a emanet edilmişti. Mustafa ve Yusuf, beraberlerinde bulunan iki nizamiye neferiyle ittifak kurarak, dört kadına sizi salıvereceğiz deyip kandırıp onları Havuzbaşı denilen yere götürüp ırzlarına geçmişlerdi. Kadınların alınan ifadelerinden ve diğer delil ve emarelerden bu suçu işledikleri tespit edilmişti. Suçları kesinleşen bu dört kişinin en ağır şekilde cezalandırılmaları için gerekli yerlere derhal yazı gönderilmişti. Kanunen Mustafa'nın polislik görevinden ihracı uygun görülmüş, Yusuf'a gereken cezanın verilmesi için ise Dersaadet Jandarma Kumandanlığına bir yazı gönderilmiştir. Ayrıca onlarla ittifak kuran nizamiyeden Koca Hüseyin ile Deli Hasan hakkında da gerekenin yapılması için kumandanlığa durum bildirilmişti. ${ }^{34}$

Yukarıdaki vakada görüldüğü üzere, polisler kendilerine verilen emre riayet etmedikleri gibi kadınları kandırıp zorla ırzlarına geçmişlerdir. Dört görevlinin kendi aralarında ittifak kurup böyle bir suça ortak olmaları, akla şu soruları getirmektedir. Polisler, bu işledikleri suçun bir cezasının olmayacağını mı düşündüler? Acaba kadınları bedenlerini satan fahişeler olarak gördükleri için mi onların gurur ve iffetlerini umursamayıp cinsi münasebette bulunma hakkını kendilerinde gördüler? Kendilerine emanet edilen kadınlar fahişe değil de başka kadınlar olsaydı, yine aynı muameleye maruz bırakılırlar mıydı? Toplumların sahip olduğu değerler, kültür ve zihniyet, bu tarz vakaların seyrinde önemli bir rol oynamaktadır. Dört görevlinin de bu suça iştirak etmesi ve böyle bir eylemi gerçekleştirmekte hiçbir çekince görmemeleri, toplumda ahlaki bozukluğun ciddi bir boyutta olduğunu mu göstermektedir? Bir vaka üzerinden kesin bir kanıya varmak mümkün olmamakla birlikte halkın, can, mal ve namusunu korumakla vazifeli olan polislerin, kendilerine emanet edilen kadınların irzına tasallut etmeleri, toplumda devlet memuruna olan güveni sarsan ciddi suçlardır. Osmanlı Devleti, toplumda huzursuzluğa ve asayişsizliğe yol açacak bu tarz suçların önünü almaya çalışmış, fahişelerle münasebet kuran, gayri ahlaki işlere bulaşan ve türlü suçlara karışan mülkiyeden talebe ${ }^{35}$ ve memurlar, jandarma, asker, polis ve zabıtalara suçlarının ağırlığına göre ihraç ${ }^{36}$, sürgün, ${ }^{37}$ hapis veya başka bir yerde istihdam ${ }^{38}$ gibi cezalar vermiştir. Ancak verilen cezalar caydırıc1 olmadığındandır ki ifşa olmaktan korkan bazı devlet görevlileri, gizli bir şekilde bu tarz suçları işlemeye devam etmişlerdir.

7 Ocak 1911 tarihli bir gazetede çıkan habere göre, Sirkeci'de bir otelde bir yüzbaşı ile üç Müslüman kızın odada birlikte kaldığına dair istihbarat alınınca polisler odayı zorla açtırıp orada bulunan kızları tutuklamışlardı. Kızların Fındıklı'da ikamet ettikleri anlaşılınca götürüp

\footnotetext{
${ }^{34}$ BOA., ZB. 77 / 20, 26 Ağustos 1302 (07 Eylül 1886).

${ }^{35}$ Mülkiye Baytar Mektebi talebesi Niyazi Efendi, daha evvel Musul bölgesine gönderilmiş ancak orada rahat durmayıp fuhşa devam etmişti. İslam'a aykırı olan bu hal ve hareketi terk etmesi için Bağdat Vilayetine gönderilmesi ve orada ikamet etmesi uygun görülmüştü. Firar etmesine meydan verilmeyerek orada ikamet ettirilmesi hususu her iki vilayete bildirilerek karar uygulanmıştı. BOA., ZB. 450 / 48, 22 Ağustos 1314 (3 Eylül 1898).

${ }^{36}$ Palanka jandarma bölüğünün Süvari Çavuşu Ahmet, sarhoşluk, Kıpti fahişe evlerinin müdavimi olma ve bir çocuğa da alaka duyma gibi kötü işlere kalkışmasından dolayı önce defalarca uyarılmış, ancak yine de hal ve hareketinde bir düzelme olmamıştı. Ayrıca bölük zabitlerine itaatsizlikte bulunmuş olduğundan durum Divan-1 Harp Şubesince tahkik edilmiş ve görevinden uzaklaştırılmasına karar verilmişti. Nitekim Ahmet istifasını vermişse de sarhoşluğu ve askeriyeye yakışmayan hareketlerde bulunmasından dolayı jandarma görevini devam ettirmesi münasip olmayacağından meslekten ihracı uygun görülmüştü. BOA., TFR.I..KV.. 203 / 20232, 02 Cemaziyelahir 1326 (02 Temmuz 1908).

${ }^{37} 1890$ yılında Almanyalı Arnest ile fuhuş yaptıkları tespit edilen polislerin görevlerinden ihraç edilerek Rodos'a sürülmeleri, uygulanan sürgün cezalarından sadece biriydi. BOA., ZB. 17/62, 26 Nisan 1306 (08 Mayıs 1890).

381847 yılında askeriyeden bazı suçlara iştirak edenler hakkında Dârûl Şura-yı Meclis tarafından alınan kararın derhal icrası için seraskere bir yazı gönderilmişti. Askeriyeden fahişelerle münasebeti olanlar ile kötü işler yapmaya meyilli olanların ceza olarak kendi memleketlerinden uzak yerlere istihdam edilmelerine karar verilmişti. BOA., Sadaret Mektubi Kalemi, (A.\}MKT.), 91 /35, 13 Şaban 1263 (27 Temmuz 1847).
} 
ailelerine teslim edilmişlerdi. Ancak yüzbaşı kaçmış ve hala yakalanamamıştı. Verilen ifadelere göre işin aslı şu şekilde cereyan olmuştu; Ayşe, Fatma ve Feride isimli üç kız yanlarında bir yüzbaşıyla sabaha doğru saat dörtte otele girmişlerdi. Hüviyetlerini otelin kayıt defterine kaydetmeleri gerekmekteydi. Ancak kadınlara bir oda tahsis edilmesine rağmen kimliği bilinmeyen yüzbaşı, deftere ismini kaydetmek istememiş ve bir firsatını bulup kaçmıştı. Kadınların hal ve hareketlerinden şüphe duyulmuş ve karakola haber verilmişti. İhbar üzerine polisler otele gelip kızları karakola götürmüss, hüviyetleri ve ikamet ettikleri yer kendilerine sorulmuştu. Ayrıca koltuk altlarında tutukları bohçaların içerisinde fahişelere mahsus elbiselerin olduğu görülmüştü. Kızlar, tesadüfen karşılaştıkları ve ismini bilemedikleri bir zabıta tarafından otele getirildiklerini ve kendilerinin Findıklı da bir mahallede ikamet ettiklerini itiraf etmişlerdi. İtirafları üzerine mahallerine götürülmüşlerdi. ${ }^{39}$

1911 senesinde İlbasan'daki cephanelik hakkında bir mesele hükümete intikal etmişti. İlbasan'daki cephanelik ve kule bekçisine birkaç el silah atıldığ 1 sonrasında nöbetçi de karşılık verdiği ancak askerler etrafa bakınmak için çıktıklarında kimseyi görmedikleri gibi iddialar üzerine hükümet, işin içinde başka bir husus olabileceği düşüncesiyle bir tahkikat yapılmasına karar vermişti. $\mathrm{Bu}$ mesele için polis ve jandarmadan oluşan bir komisyon kurulmuş, yapılan tahkikatla işin aslı farklı olduğu anlaşılmıştı. Cephaneliğin muhafazasından sorumlu olan bir onbaşı ile Şevket namındaki nefer, civar çayırlığa götürdükleri bir fahişeden dolayı aralarında kavga çıkmış ve kavgada attıkları birkaç el silah üzerine durumdan haberleri olmayan diğer askerler de ateş açmışlardı. ${ }^{40}$ Vazifeleri hususunda gereken itinayı göstermeyen bu askerler, korumakla yükümlü oldukları cephaneliğe fahişe getirmekle kalmamış sonrasında birbirleriyle kavgaya tutuşarak büyük bir soruna sebebiyet vermişlerdi. Benzer başka bir vaka ise Ferit Paşa Köşkünde meydana gelmişti. Sadrazam Ferit Paşa Köşkü'nün muhafazasına memur kılınmış inzibat efradından sekiz nefer, köşkün bahçesindeki ikamet ettikleri karakola fahişe bir kadın getirerek eğlenmekte oldukları, polis ve jandarmalar tarafından görülünce yakalanmaları için harekete geçilmişti. Ancak bunlardan Çavuş Ali isimli nefer, elindeki silahla iki defa ateş açması üzerine silah sesi işitilmiş ve durum merkez kumandanlığa ihbar edilmişti. Gelen ihbar üzerine polis merkez kumandanıyla polis memurları olay yerine gelerek suçluları tevkif etmiş ve fahişe kadın ise polislere kendisi teslim olmuştu. ${ }^{41}$

Bir fahişenin ölümüyle sonuçlanan, askerin müdahil olduğu bir vaka ise şu şekilde cereyan etmişti; Bahriye askerlerinden 8-9 kişi, üç fahişe ile Çengelköy'ün Talimhane Meydanı Mahallesi'nde bir boş köşkte fuhuş eyledikleri halde men edilmemişlerdi. Ancak bu duruma tahammül edemeyen mahalle sakinlerinin bizzat onları yakalamaya teşebbüs edecekleri ihbar edilmesi üzerine dört polis ve beş jandarmadan müteşekkil bir devriye olay yerine intikal etmişti. Bahriye askerlerinden Ferhan Çavuş yakalanmış, ancak arkadaşlarından Şakir, Salih, Osman Çavuş, Trabzonlu Mustafa, İbrahim ve kimlikleri kesin olmayan Mehmet ve Süleyman, gelen memurlara hücum edip karşı çıkmaları üzerine aralarında çatışma çıkmıştı. Jandarma Ömer tarafından atılan iki el ateş üzerine daha fazla karşı koyamayarak hepsi firar etmişti. Firarilerin kendilerini müdafaa eyledikleri noktaya polisler geldiğinde, çatışma esnasında fahişelerden Leman'ın başına yediği kurşundan dolayı yere düştüğü ve aldığı bu yaradan dolayı vefat ettiği tespit edilmişti. Firariler ise yapılan takibatla tutuklanıp adliyeye teslim edilmişlerdi. ${ }^{42}$ Leman isimli fahişe, çatışmanın ortasında kaldığ 1 için polisler tarafından kazara öldürülmüştü. Leman gibi kazara olmasa bile devlet görevlileri tarafından öldürülen başka fahişe kadınlar da vardı. Cesedi bir derede bulunan Fahriye de bunlardan biriydi. Etraflıca

${ }^{39}$ BOA., DH.EUM.KADL 4/38, 13 Muharrem 1329 (14 Ocak 1911).

${ }^{40}$ BOA, Dahiliye Nezareti Hukuk (DH. H...), 52/6, 11 Recep 1329 (08 Temmuz 1911).

${ }^{41}$ BOA, Dahiliye Nezareti Asayiş Şubesi, (DH.EUM.AYŞ.), 42 /34, 09 Şevval 1338 (26 Haziran 1920).

${ }^{42}$ BOA, DH.EUM.THR. 34 /55, 19 Cemazeyilevvel 1328 (29 Mayis 1910). 
yapılan tahkikatlar neticesinde, Fahriye'nin iki asker tarafından öldürüldüğü ortaya çıkarılmışt1. ${ }^{43}$ Ancak bu tür hadiselerde öldürülen sadece fahişeler değildi, fahişelerle münasebeti olup onlar tarafindan öldürülen devlet görevlileri de vard. ${ }^{44}$

Askerlerin fahişelerle gizli münasebetler kurarak tertip ettikleri eğlenceler kimi zaman bir baskına uğrayarak başlarına büyük sorunlar açabilmekteydi. Saraybosna'da ikamet eden Salih, Fazıl, Mehmet ve Şaban, bir binbaşının maiyetinde bir müddet hizmette bulunduktan sonra hesaplarını keserek memleketlerine dönmek üzere Yanya'ya gelip eve fahişe almışlardı. Etrafta gezinmekte olan Yüzbaşı Mehmet Ağa, o hanenin olduğu yerden geçerken tesadüfen duruma şahit olmuş ve hemen karakola haber vermişti. Hemen yanına bir mülazım ve birkaç zaptiye alarak olay mahalline gitmişti. Kaçan olmasın diye evin ön tarafı zaptiyeler tarafından tutulmuş diğer taraftan da asker içeriye girmeye çalışmış ancak içeridekiler durumun farkına varıp yanlarındaki silahlarla üç el ateş etmişlerdi. Çıkan kurşunlardan biri Binbaşı Mustafa Ağa'ya diğeri ise Mehmet adındaki zaptiyeye isabet etmesiyle Mehmet orada ölmüş, Mustafa ise hanesine götürülmüştü. Derhal olay yerine daha fazla asker sevk edilmiş ve 5 suçlu da sağ ele geçirilerek hapse atılmışlardı. Binbaşı Mustafa ise aldığı o ağır yaradan dolayı tüm müdahalelere rağmen ölmüştü. ${ }^{45}$

Başka bir vakada ise, Dersaadet Orduyu Hümayun piyade alayından Mülazım Ali ve arkadaşları değirmende üç fahişeyle yemek yerken on bir kişi, üzerlerine hücum ederek ellerinden silahlarını alıp sopalarla mülazımı yaralamışlardı. Mahkemeye çıkarılan bu on bir kişiden üçü tahliye edilmiş, sekizi ise pranga cezasına çarptırılmaları uygun görülmüş, ancak dava nihai karar için Meclis-i Vâlâ'ya intikal ettiğinde ceza müddetlerinde değişikliğe gidilmişti. Suçlulardan sekizi, mülazıma silah çektiğinden ve askere silah çekenlerin kanunen üç aydan üç seneye kadar pranga cezasına çarptırılmaları gerekmekteyse de bunların altışar ay müddetle prangaya konulmaları ve ceza bitiminde tahliyelerine karar verilmiştir. ${ }^{46}$

Osmanlı'da köy ve mahalle sakinleri, toplumun dini ve ahlaki değerlerine gereken hassasiyeti göstermeyip aile üyelerine bilhassa kız ve erkek çocuklara kötü örnek teşkil eden idarecileri yakın takibe alarak bir ahlaksızlıklarını duyduklarında veya gördüklerinde toplanarak evlerine baskın vermekteydiler. Osmanlı' da evlerinde içkili eğlenceler düzenleyen, evlerine gizli bir şekilde fahişe alan veya bir fahişeyi koruması altına alıp kapatması yapan mülkiye memurlarının sayısı azımsanmayacak kadar fazlaydı. ${ }^{47} \mathrm{Bu}$ uygunsuz hareketlerde

\footnotetext{
431909 yllında Çenkelköy'deki Arnavut Deresi'nde fahişe Fahriye'nin cesedi bulunmuştu. Öldürüldüğü tespit edilmesi üzerine hemen tahkikat başlatılmıştı. Tahkikat neticesinde bahriye mirlivalarından Rıza Paşa'nın yanında çalışan Onbaşı Hasan'ın elbisesindeki kan lekesi, korkmuş hali ve verdiği ifade ve yine aynı şekilde korkup kaçmış ve daha sonra yakalanmış olan İsmail'in dahi ceketinde benzer kan lekeleri tespit edilmesi, bu suçu ikisinin işlemiş olduğunu göstermekteydi. Ayrıca her ikisinin de ruhen ve bedenen inanılmaz derecede heyecan ve endişe içerisinde olmaları ve bulunan deliler bu suçu işlediklerini kanıtlamaktaydı. Onbaşı Hasan'ın fahriyeyi öldürdüğü, İsmail'in ise ona yardım ederek cesetti kuyuya attı̆̆ 1 yapılan tahkikatla ortaya çıkarılmıştı. Bunun üzerine tahkikat raporu ve suçlular adliyeye sevk edilmişlerdi. BOA., DH.EUM.THR. 91 /42, 08 Şevval 1327 (M. 15 Ekim 1909).

${ }_{44} 1891$ y1lında hükümet, Galata'da öldürülen Faik Bey'in öldürülme nedenin tahkik edilmesi istenmiști. Bunun üzerine olay tahkik edilmiş ve işin aslı ortaya çıkarılmışı. Faik Bey, yanında bulundurduğu fahişe bir kadınla şakalaşırken, kadının attığı bıçağın ayağındaki damara isabet etmesiyle ölmüş olduğu ortaya çıkarılmıştı. BOA., Yıldız Sarayı Sadaret Hususi Maruzat Evrakı, (Y..A...HUS.), 250/34, 14 Muharrem 1309 ( 20 Ağustos 1891).

${ }^{45}$ BOA, Meclis-i Vala Riyaseti Belgeleri, ( MVL.), 908/ 55, 13 Cemazeyilahir 1276 (07 Ocak 1860).

${ }^{46}$ BOA, Sadaret Mektubi Kalemi Meclis-i Vâlâ, (A.\}MKT.MVL.), 10/61, 07 Zilkade 1264 (05 Ekim 1848).

${ }^{47}$ Manastır Maarif Müdürü Alâeddin Efendi'nin de evine Vaso isimli bir fahişe getirdiği bazı kimseler tarafından görülmesi üzerine bu mesele hakkında tahkikat yapılmıştı. Vaso, Alaeddin Efendi'nin hizmetkârı vasıtasıyla aldığı haber üzerine fuhuş yapmak maksadıyla eve gittiğini ifadesinde itiraf edip suçunu kabul etmişti. Ayrıca bu işe ön ayak olanlardan biri de Tuman idi. Tuman, kendisine bir fahişe getireceğini Alaeddin Efendi' ye vaat etmiş ve bunu da ifadesinde ayrıntılı bir şekilde Vaso gibi itiraf etmişti. BOA, Maarif Nezareti, Mektubi Kalemi (MF.MKT.) 319/ 8, 28 Zilhicce 1313 (10 Haziran 1896).
} 
bulunanların bölgenin idarecileri olması ahalide daha büyük öfke ve şiddete sebep olmaktaydı. Diğer taraftan bölge idarecileriyle husumeti bulunan, devlete karşı hain duygular besleyen ve çıkarları uğruna kaos yaratmak isteyen bazı kimseler, toplumun fuhuş ve fahişeler hususundaki bu hassasiyetinden istifade ederek halk1 galeyana getirip evlere ve konaklara baskın düzenleyerek huzur ve asayişi bozmaktaydılar. Osmanlı Hükümeti, her ne sebeple olursa olsun halkı galeyana getirip evlere baskın verdiren, umumi ahlaka aykırı harekette bulunup ahalinin tepki ve öfkesine yol açan ve vazifelerinin gereğini yerine getirmeyip görevlerini suiistimal eden her kim olursa olsun haklarında kanuni takibat başlatarak cezalandırmıştır. Osmanlı Hükümeti'ne bu hususta intikal etmiş birkaç vaka şu şekildeydi:

1908 yılında evinde fahişe bulunduran Mülazım Cemal Efendi'ye karşı mahalle sakinleri toplanması üzerine dağıtılmış, ancak tekrar toplanmışlardı. Zaptiye ve askerin yardımlarıyla dağıtılan halkın tekrar toplanmasına süvari mülazımlarından Recep Efendi'nin sebebiyet verdiği yapılan tahkikatta anlaşılmıştı. Recep Efendi'nin mülkü askeriyede bulunmamak şartıyla hakkında kanuni muamelenin icrası lüzumu Ordu-yu Hümayun kumandanlığına yazılması üzerine Recep'in Selanik'e gönderilmesine karar verilmişti. Halkın toplanmasına sebebiyet verdiği ve dağılmaları için yapılan uyarılara kulak asmayarak 1srarcı olmaları fikrini halka verme cüreti gösteren polis memurlarından Kamil Efendi hakkında dahi kanuni işlemin yapılmasına karar verilmiş ve hakkında gereken hüküm verilene kadar İştib'de bulunması münasip görülmeyerek vilayete gönderilmesi istenmiştir. ${ }^{48}$

Benzer bir olay da Sapanca'da meydana gelmişti. Evinde fahişe bir kadın bulundurduğu sebebiyle mahalle sakinleri tarafından Sapanca müdürü Zeki Bey’in evi kuşatılmıştı. Gelen bu ihbar üzerine hemen olay yerine polis memurları gidip vaka hakkında tahkikat yapmışlardı. Yapılan tahkikata göre müdürün evinden bir kadının çıkmış olduğu bazı şahitler tarafından ifade edilmiş ve Hacı Musa ve Hacı Mustafa gibi daima hükümet aleyhinde harekette bulunan bazı kişilerin tahrik ve teşvikiyle müdürün evine saldırı olmuştu. İnsanları böyle galeyana getirip ortalığı karıştıranların tutuklanarak adliyeye teslim olunmak üzere haklarında gerekli cezanın icrasına ehemmiyet gösterilmesi hususu Adapazarı Kaymakamlığına bildirilmiş, müdür hususunda ise müdüre isnat olunan suçun tahkiki sürecinde orada memuriyetine devam etmesi caiz olmayacağından tahkikatın hemen yapılarak neticesinin bildirilmesi istenmiştir. ${ }^{49}$ Hükümet, hem ahaliyi galeyana getirenler hem de evine fahişe alan müdür hakkında tahkikat başlatmış ve müdürün memuriyetine devam etmesini uygun görmemiştir. Bursa ve Osmancık Kasabası'nda da benzer olaylar zuhur etmiş ve haklarında görevlerinden azledilme kararı alınmıştır.

Osmancık Kasaba halkından bazıları, Kaymakam Ali Rıza Efendi'nin evinin etrafina toplanarak eve saldırıp hakaret etmeleri üzerine zabıta vaktinde yetişip bir fenalık zuhuruna meydan vermeksizin onları dağıtmıştı. Kaymakamın evine fahişe bir kadın almasından dolayı bu hadisenin yaşandığ 1 ve bu sebeple orada memuriyetine devam etmesi uygun olmayacağ 1 yapılan tahkikatla anlaşılmış, işinden el çektirerek yerine bir vekil tayin edilmişti. Kendisinin ise başka münasip bir kazaya tayin edilmesi hususu hükümete bildirilmişti. Kaymakamın bu ahvalinden dolayı başka yere nakli caiz olmayacağından azledilip yerine Ürgüp Kaymakamı Atıf Efendi'nin tayini uygun görülmüştü. Ancak ahalinin tepkisini alan ve görevinde başarısız olan kaymakamın azli uygun olmayacağından diğer kaza kaymakamıyla yer değiştirmelerine karar verilmiştir. ${ }^{50}$

${ }^{48}$ BOA, TFR.I..KV.. 210 /20945, 11 Ramazan 1326 (07 Ekim 1908).

${ }^{49}$ BOA, DH.MKT. $1103 / 65,06$ Cemazeyilahir 1324 (28 Temmuz 1906).

${ }^{50}$ BOA, DH.MKT. 1101 /78, 27 Cemazeyilevvel 1324 (19 Temmuz 1906). 
Bir diğer benzer vaka da Bursa'da yaşanmıştı. Tedbir olarak kişi hemen görevinden azledilmişti. Hükümet haksızlık yapılıp yapılmadığını tespit etmek amacıyla azledilme nedeni hakkında bilgi istemiştir. Bursa'da vali vekaletinde bulunduğu sırada, Bursa'nın Eşrefiler Mahallesi sakinlerinden İbrahim Naim Efendi'yi usule aykırı bir şekilde tutuklayıp İstanbul'a süren Van Valisi Tahsin Bey'e bu meselenin hakikatinin ne olduğu ve ne sebeple İbrahim Bey'i sürdüğü sual edilmişti. Tahsin Bey'in gönderdiği cevapta yazılanlara göre, "İbrahim Naim Efendi, halkın huzursuz ve ortalığın karışık olduğu bir zamanda hanesine üç fahişe kapatması, toplumda infiale yol açmış, üç fahişe de insanların gözü önünde evden çıkarılmıştı. Bu sebepten dolayı meydana gelen galeyan teskin edilmeye çalışılmış, İbrahim Efendi derhal memuriyetinden azledilmişti. Bütün Osmanlılar için elem ve hüsran olan böyle bir günde İbrahim'in böyle harekete bulunmasını doğru bulmayan halkın İbrahim'in aleyhinde kötü fikirleri olduğu ve toplanıp ona bir şeyler yapacakları polisler tarafından bildirilmesi üzerine hem canını hem de emniyetini muhafaza etmek adına İstanbul'a gitmesi lüzumu polis tarafından İbrahim'e bildirilmişti. Adliye bu meseleyle alakadar olmamış ve kanuni bir durum olarak görülmediğinden meclise intikal etmediği gibi tevkif emri de verilmemişti. ${ }^{, 51}$ Bursa Vali vekiliyken bu azli gerçekleştiren Van Valisi, ülkenin içerisinde bulunduğu bu zor günlerde halkın çok daha hassas olduğunu hem halkı teskin etmek hem de bu suçu işleyenin can ve malını muhafaza edebilmek adına azli gerçekleştirip kişiyi İstanbul'a gönderdiğini ifade etmiştir. 1912 ve 1913 yılları devletin Batı'da Balkan savaşları, Doğu'da Ermeni-Kürt çatışmalarıyla mücadele ettiği yıllardı. Bu dönemde ülke hem ekonomik hem de siyasi olarak oldukça sıkıntılı günlerden geçmekteydi. Bu vakada da görüldüğü üzere toplumda asayiş, emniyet ve sükûneti sağlamak adına idareciler, bu sıkıntılı dönemlerde daha temkinli davranmak ve gerekli her türlü tedbiri almak zorundaydılar.

Osmanlı'da sadece askeriyeden ve mülkiyeden memurlar değil aynı zamanda bazı ticari imtiyazlara sahip yabancılar da evlerine fahişeler alarak ve onlarla gizli münasebetler kurarak ahalinin tepkisine yol açmıştır. Karahisar'a bağlı Esçe karyesindeki mermer maddeni imtiyazına sahip olan Mösyö Baron, Karahisar kasabasında çarşı arasında olan evine iki Müslüman fahişe kadını götürdüğü ahali tarafından haber verilmesi üzerine zaptiye yüzbaşısı Hacı Şevki maiyetiyle birlikte olay mahalline giderek orada toplanmış olan ahaliyi dağıtmıştı. Malumat üzerine kapı açtırılmış, Polis Hasan Efendi bizzat içeri girip içerde kimsenin olmadığını beyan etmiştir. Fransız tebaasından olan Baron, bekâr olup iddialara göre her iki günde bir fuhuş yapmaktaydı. Baron'un bu çirkin hareketi ahalide huzursuzluğa ve şikâyete neden olmuş, bu durumun ilerde büyük bir fenalığa yol açacağından endişe duyan yerel idareciler, konsolos vasıtasıyla Baron'un bu hareketinden ötürü şiddetli bir şekilde uyarılmasını talep etmişlerdi. ${ }^{52}$

\section{Sonuç}

Fuhşun ve ahlaki sorunların yaygınlaşmasında en önemli sebep olarak genellikle ekonomik sorunlar gösterilmektedir. Ancak fuhşun artmasında ve kadınların bedenlerini satarak fahişeliği kendilerine meslek edinmelerinde tek ve geçerli sebep olarak ekonomik durumları öne sürmek doğru yaklaşım olmaz. Kadınların fahişelik yapmalarında para ve ekonomik sorunların etkisi yadsınmamakla birlikte, toplumsal baskı, şiddet, tehdit, psikolojik, ailevi, kültürel, cinsel ve daha birçok sebep de sayılabilir. Osmanlı Devleti'nde zorla fuhuş yaptırılan, ailelerinden koparılarak fahişelik yapmaya mecbur bırakılan, tehditlerle çeşitli suçlara bulaştırılan, ellerindeki paralara el koyulan, fahişedir deyip ırzlarına geçilen, direndiklerinde veya itaat

\footnotetext{
${ }^{51}$ BOA, Dahiliye Nezareti Emniyet-i Umumiyye Evrak Odası Kalemi Evrakı (DH. EUM. VRK.) 27/35, (H. 23 Safer 1332 / M. 21 Ocak 1914).

${ }^{52}$ BOA, DH. ŞFR. 172/48, (H. 11 Mart 1311 / M. 23 Mart 1895).
} 
etmediklerinde canlarından olan kadınlar, her ne kadar toplumdaki birçok ahlaksızlığın müsebbibi olarak görülseler de arzuhallerdeki vakalardan da anlaşlacağı üzere toplum ve toplumun düzen ve asayişinden sorumlu bazı devlet görevlileri tarafindan da bu yola itildikleri görülmektedir.

Osmanlı'da ekonomik sıkıntıların arttığ savaş dönemlerinde devletin alt ve üst kademelerinde görev yapan memurların fuhuş, içki, kumar, rüşvet ve yolsuzluk gibi gayri ahlaki yollara daha fazla saptıkları görülse de ahlaki yönden zayıf olanlar, kötü veya iyi koşullara bağlı olmadan devlet memuruna yakışmayan bu tarz bir yaşamı her dönem devam ettirmişlerdir. Merkezi denetimin nispeten daha güçlü olduğu dönemlerde, devlet haklarında şikayet olan memurları, diğerlerine emsal olacak şekilde cezalandırarak, memura yakışmayacak davranışların önünü almaya çalışmıştır. Suçun ağırlığına göre farklı cezalar uygulanmıştır. Ancak suçun tespiti burada büyük bir önem arzetmektedir. 1833-1922 y1lları arasında farklı tarihlerde devlete intikal eden memurların müdahil oldukları fuhuş ve fahişe meseleleri üzerine yapılan incelemede, şikayete bağlı olarak soruşturmaların açıldı̆̆ 1 ve suçun tespitinde, halktan ve yöneticilerden gelen arzuhallerin büyük bir öneme sahip olduğu ve hatta en önemli adım olduğu anlaşılmaktadır. Diğer bir ifadeyle, haklarında şikâyet intikal etmediği sürece umumi ahlaka aykırı suçları tespit etmek pek mümkün olmadığı gibi eğer fuhşa ve fahişelere aracılık eden veya onlarla cinsel münasebet kuranlar, devletin üst kademelerindeki memurlar ise yetkilerini kötüye kullanarak şikâyetleri örtbas edebildikleri gibi olayları manipüle edip halkı ve merkezi hükümeti de yanıltabilmekteydiler.

Memurların müdahil olduğu fuhuş ve fahişelerle ilgili incelenen yaklaşık 40 vakadan sadece 5'i mülkiye memurlarıyla ilgili olup büyük bir kısmının askeriyeden memurlarla ilgili olduğu tespit edilmiştir. Ancak asker, jandarma, polis, zabıta gibi kolluk kuvvetlerinin gayri ahlaki yollara sapmalarındaki nedenleri birkaç vaka üzerinden irdeleyerek genel bir yargıya varmak pek mümkün değildir. Osmanlı Devleti, farklı din, dil ve etnik unsurların bir arada yaşadığ coğrafyada hüküm sürmekteydi. Merkezi hükümete ülkenin farklı yerlerinden farklı tarihlerde gelen birkaç şikayetten ancak Osmanlı'da fuhuş ve fahişe meseleleriyle ilgili nerede ne tür vakalar yaşandığı, devletin bu tarz suçlara yönelik aldığı tedbir ve uyguladığı cezalar tespit edilebilmektedir. Diğer taraftan bu tarz vakalardan devlet ve toplum ilişkilerinde ahlaki sorunların ne gibi sonuçlar doğurabildiği de öngörülebilmektedir. Bayrut'ta bir Müslüman fahişenin Hıristiyan bir erkekle basılması sonucunda günlerce süren ayaklanma ve çatışmaların yaşanması (Beyrut, 1860), hükümete gönderilen jurnallarde gayri ahlaki yollara sapmış olan memurlar cezalandırılmaz ve fuhuşun önü alınmazsa büyük hadislerin yaşanacağının ifade edilmesi (İzmir, 1893), evlerine fahişe alan idarecilerin ahali tarafından evlerinin basılması (Osmacık, 1906), bir fahişe meselesi yüzünden karokolun basılıp bir çavuşun ahali tarafından öldürülmesi (Kars, 1833) gibi hadiseler, Osmanlı'da farklı tarihlerde ve bölgelerde yaşanmış olsa da toplumun ahlaki sorunlara olan yaklaşımında aslında pekte bir değişim olmadığ görülmektedir. Başka bir ifadeyle, toplumun hassas olduğu konulara karşı daha ihtimamlı davranması gereken devlet memurlarının, sahip oldukları unvan ve makamlarının arkasına sığınarak uygun olmayan hal ve hareketlerde bulunmaları ve nizam ve asayişi sağlamamaları, bir noktada halkta güvensizliğe ve huzursuzluğa yol açtığı ve birkaç vakadan da tespit edildiği üzere gayriahlaki durumlarda halk, idarecilerden ve kolluk kuvvetlerinden medet ummayıp kendilerince adaleti tesis etmeye çalıştıkları görülmektedir. Ayrıca devlete karşı düşmanca fikir ve duygular içerisinde olanların, toplumun inanç ve değerlerine yönelik hassasiyetlerinden istifade ederek halkı galeyana getirip kaos ortamı yaratarak devleti zayıflatmaya çalıştıklarına dair devlete intikal etmiş bir vakada oldukça dikkat çekicidir (Adapazarı, 1906). Memurların ahlaki zayıflıkları, sadece kendilerine değil, devletin itibarına ve güvenirliliğine de zarar verebilmekteydi. 
Sonuç olarak fuhuş ve fahişe meselelerine sadece ahlaki açıdan bakmak ve böyle bir değerlendirme yapmak, doğru bir yaklaşım olmayacağı kanaatindeyiz. Devlet görevlilerin müdahil olduğu fuhuş ve fahişe meseleleri, devlet ve toplum ekseninde ele alınması gereken çok boyutlu, multidisiplinler bir konudur. Bir memurun müdahil olduğu ahlaki bir sorun, toplumun sahip olduğu dinamiklere bağlı olarak, toplum ve devlet ilişkisini zedeleyebildiği gibi farklı sorunlara da yol açabilmiştir. Toplumlardaki gerilimin yüksek olduğu dönemler, özellikle ekonomik sıkıntıların yaşandığı savaş yıllarıdır. Açlık, sefalet, ahlaki çöküntünün arttığı bu yıllar aynı zamanda toplumun devletten beklentilerinin daha fazla olduğu yıllardır. Merkezi idarenin zayıflaması ve buna bağlı olarak beklentilerin karşılanmaması, her an ayaklanmalara ve kargaşaya hazır huzursuz bir toplum yaratmaktaydı. Böyle zamanlarda devleti temsil eden idari ve askeri memurların gayri ahlaki tutumlar içerisinde olması ise bazı vakalardan da anlaşıldığı üzere Osmanlı toplumunda, devlete karşı nefret ve öfkeye yol açmıştır.

\section{Kaynakça}

\section{Devlet Arşivleri Başkanlığı Osmanlı Arşivi (BOA.)}

Sadaret Mektubi Kalemi, (A.\}MKT.): 91 /35.

Sadaret Mektubi Kalemi Meclis-i Vâlâ, (A.\}MKT.MVL.): 10/61.

Sadaret Mektubi Kalemi Umum Vilayet (A.\}MKT.UM..): 533/70; 414/3.

Dahiliye Nezareti Emniyet-i Şubesi Takibat-1 Adliye Kalemi, (DH. EUM. ADL.): 32 /28.

Dahiliye Nezareti Asayiş Şubesi, (DH.EUM.AYŞ.): 42 /34.

Dahiliye Nezareti Emniyyet-i Umumiye Müdiriyyeti Kısm-1 Adli Kalemi, (DH.EUM.KADL.): $4 / 39 ; 4 / 38$.

Dahiliye Nezareti Emniyet-i Umumiye Tahrirat Kalemi (DH. EUM. THR.): 44/5; 34 /55; 91 142 .

Dahiliye Nezareti Emniyet-i Umumiyye Evrak Odas1 Kalemi Evrakı (DH. EUM. VRK.): $27 / 35$.

Dahiliye Nezareti Hukuk (DH. H...): 52/6.

Dahiliye Nezareti İrade-i Umumiye Müdüriyeti ( DH.İ.UM.): 19 /1.

Dahiliye Mektubi Kalemi (DH.MKT.): 1101 /78; 1535/ 90; 1103 /65; 1101 /78; 1197/ 51.

Dahiliye Hapishaneler Müdüriyeti (DH. MP.. HPS.): 89/23.

Dahiliye Nezareti Şifre Kalemi (DH.ŞFR.): 243/ 65; 172/48.

Hatt-1 Hümayun (HAT.): 301 / 17897.

Maarif Nezareti, Mektubi Kalemi (MF.MKT.): 319/ 8.

Meclis-i Vala Riyaseti Belgeleri, ( MVL.): 908/ 55.

Rumeli Müfettişliği Kosova Evrakı (TFR.I..KV.. ): 210 /20945; 203 / 20232; 210 /20945.

Teftişat-1 Rumeli Evrakı-Selanik Evrakı (TFR. I. SL.): 66/6533.

Yıldız Sarayı Sadaret Hususi Maruzat Evrakı, (Y..A...HUS.): 250/34.

Yıldız Tasnifi Perakende Evrakı Mütenevvi Maruzat Evrakı,(Y..MTV.): 47 /185.

Yıldız Tasnifi Perakende Arzuhaller ve Jurnaller, (Y..PRK.AZJ.): 24/48; 21 /65. 
Osmanlı Devleti'nde Memurların Müdahil Olduğu Bazı Fuhuş ve Fahișe Meseleleri Üzerine...

Zaptiye Nezareti Belgeleri (ZB.): 366/107, 09 Şubat 1323 (22 Şubat 1908); 77 / 20; 450 / 48; $17 / 62$.

\section{Araştırma Eserler}

ACAR, İsmail. "Osmanlılarda Zina Suçu ve Cezası", Türkler, C. 10, Yeni Türkiye Yayınları, Ankara, 2002, s.149-163.

ACAR, Kezban, "Osmanlı Devleti’nin Son Yüzyılında Fuhşu Önleme Çabalarına Dair Bazı Tespitler (1810lar-1910lar)", History Studies, C.10, S.9, Aral1k 2018, s.1-19.

BOZKURT, Nebi, "Fuhuş", Türkiye Diyanet Vakfi İslam Ansiklopedisi, C.13, Türkiye Diyanet Vakf1 Yayınları, İstanbul, 1996, s.211-214.

ÇETIN, Cemal, "Osmanlı Toplumunda Mahalleden İhraç Kararları ve Tatbiki: Konya Örneği (1645-1750)", History Studies, C.6, S.6, Aral1k 2014, s.4370.

ÇABUK, Fehminaz, "19. Yüzyılda Osmanlı'da Zina Suçu: Bazı Zina Davları ve Tatbik Olunan Cezalara Dair Bir Değerlendirme", Tarih Okulu Dergisi, C.12, S.XL, s.401-424.

DEVELLİĞLUU, Ferit, Osmanlıca-Türkçe Ansiklopedik Lûgat, Aydın Kitabevi, Ankara, 2012.

EKİNCİ, Ekrem Buğra, İslam Hukuku Umumi ve Hususi Hükümler, Arı Sanat Yayınları, İstanbul, 2016.

ELDEM, Edhem, Daniel Goffmann \& Bruce Masters, Doğu İle Batı Arasında Osmanlı Kenti Halep İzmir ve İstanbul, Çev: Sermet Yalçın, Türkiye İş Bankası Kültür Yayınları, İstanbul, 2017.

ESEN, Hüseyin, "Zina”, Türkiye Diyanet Vakfi İslâm Ansiklopedisi, C. XLIV, Türkiye Diyanet Vakfı Yayınları, İstanbul 2013, s.440-444.

GEZER, Onur, “Çizginin Dışındakiler: Osmanlı İstanbul'unun Aykırı Bekârları ve Bekâr Girer Melek Girmez Odaları", Osmanlı İstanbul'u II, s.523-552.

KARAY, Refik Halid, Memleket Hikâyeleri, İnkılâp Yayınları, İstanbul, 2019.

KILIÇARSLAN, Ramazan, "Refik Halit Karay’ın Sarı Bal Adlı Hikâyesi Üzerine Bir Tahlil Denemesi”, Uşak Üniversitesi Sosyal Bilimler Dergisi, C.8, S.4, 2015, s.175-186.

KIRLI, Engin, “Tanzimat Sonrası Fuhuş Hadisesine Yaklaşımda Yaşanan Değişim”, Süleyman Demirel Üniversitesi Sosyal Bilimler Enstitüsü Dergisi, C.2, S.12, 2012, s.39-51.

KOÇ, Emre "Osmanlı Mahallesinde Cemaat İçi Ahlaki Oto-Kontrol Sistemi: Suç İle Suçlunun Tespiti Kavramlaştırılması ve Suçlunun Dışlanması (İhraç)", Akademik Bakış Dergisi, S.71, 2019, s.120-148.

KÖSE, Osman, "XVIII. Yüzyıl Sonları Rus ve Avusturya Savaşları Esnasında Osmanlı Devletinde Bir Uygulama: İstanbul'da İçki ve Fuhuş Yasağı", Turkish Studies, C.2, S.1, 2007, s.104-123.

KÖŞELİ, Yusuf, "Evrensel Bir Tema Olarak Düşmüş Kadın: Fantine, Marta El-Bânî ve Yatık Emine", Tarih Okulu Dergisi, C.7, S.20, s. 415-428.

MUTAF, Abdülmecit, “Teorik ve Pratik Olarak Osmanlı'da Recm Cezası: Bazı Batı Anadolu Şehirlerindeki Uygulamalar", Turkish Studies, C.3, S.4, 2008, s. 573-597. 
OSMANAĞAOĞLU, Cihan, "Klasik Dönem Osmanlı Hukukunda Zina Suçu ve Cezası", IÜHFM Dergisi, C.LXVI, S.1, 2008, s.109-178.

SABEV, Orlin, "Ahlakın Arka Sokakları: 18. Yüzyıl Osmanlı İstanbul'unda Fuhuş ve Ceza”, Osmanlı Ístanbul'u IV, s.621-642.

Şemsettin Sami, Kâmûs-ıTürkî, Çağrı Yayınları, İstanbul, 2007.

“Türk Ansiklopedisi’nde Refik Halid Karay “,Tarih ve Toplum, İletişim Yayınları, S.13, 1985.

TÜMER, Günay, "Fuhuş", Türkiye Diyanet Vakfi İslam Ansiklopedisi, C.13, Türkiye Diyanet Vakf1 Yayınları, İstanbul, 1996, s.209-211.

ÜÇOK, Coşkun, "Osmanlı Kanunnamelerinde İslam Ceza Hukukuna Aykırı Hükümler”, Ankara Üniversitesi Hukuk Fakültesi Mecmuası, C.3, S.1, 1946, s.125-146.

YETKIN, Aydın, "II. Meşrutiyet Dönemi’nde Toplumsal Ahlak Bunalımı: Fuhuş Meselesi”, Tarihin Peşinde Uluslararası Tarih ve sosyal Araştırmalar Dergisi, S.6, 2011, s.21-54.

YILMAZ, Fikret, "Zina Fuhuş Arasında Kalanlar, Fahişe Subaşıya Karşı”, Toplumsal Tarih, Nisan, 2012, ss.22-30.

ZİLFI, Madeline C., Osmanlı İmparatorluğunda Kölelik ve Kadınlar (1700-1840), Çev. Ebru Kı1ıç, Türkiye İş Bankası Kültür Yayınları, İstanbul 2018.

Volume 12

Issue 4

August 